\title{
Señoritas and Cigarmaking Women: Using 'Latin' Feminine Types to Rebrand and Market Ybor City, 1950-1962
}

\author{
Brad Massey \\ Polk State College \\ I. j. russum \\ Polk State College
}

Follow this and additional works at: https://digitalcommons.usf.edu/sunlandtribune

Part of the United States History Commons

\section{Recommended Citation}

Massey, Brad and russum, I. j. (2017) "Señoritas and Cigarmaking Women: Using 'Latin' Feminine Types to Rebrand and Market Ybor City, 1950-1962," Sunland Tribune: Vol. 34 , Article 8.

https://doi.org/10.5038/2575-2472.34.7

Available at: https://digitalcommons.usf.edu/sunlandtribune/vol34/iss1/8

This Research Article is brought to you for free and open access by the Open Access Journals at Digital Commons @ University of South Florida. It has been accepted for inclusion in Sunland Tribune by an authorized editor of Digital Commons @ University of South Florida. For more information, please contact digitalcommons@usf.edu. 


\section{Señoritas and Cigarmaking Women:}

\section{Using 'Latin' Feminine Types to Rebrand and Market Ybor City, 1950-1962}

Peer reviewed

Brad Massey and I.j. russum

\begin{abstract}
"Pretty señoritas" and "tractable" cigarmaking women were two Latin female types created by marketers to promote Ybor City-historically known for industrial cigar production, Latin immigrants, and labor strife-as both a major tourist destination and continuing cigar manufacturing center after World War II. This article-through an examination of promotional materials, news accounts, and other archival sources-describes how Anthony Pizzo, Tampa mayor Curtis Hixon, and other area businesspersons and politicians used señoritas and female cigar workers to rebrand and market postwar Ybor City as a distinct and exotic hybrid space, which combined industrial production with tourist-centered consumption.
\end{abstract}

\footnotetext{
${ }^{1}$ The Alcalde program was created in 1952, and was charged with publicizing and encouraging capital investment in Ybor City. The Alcalde program/initiative is described at length later in this essay. Scholars have examined the use of female sexuality in Florida advertising and promotional campaigns, but not the 'pretty señorita' construct created by Tampa's promoters. See Nicole C. Cox, "Selling Seduction: Women and Feminine Nature in 1920s Florida Advertising," 89 (Fall 2010): 186-209 and Shemuel Fleenor, "Manufacturing the 'Magic
}

This essay opens with a description of the creation and utilization of the promotional Ybor señorita. Like the 'Southern Belle' archetype used in Mississippi and other regions of the Deep South to market Confederate Lost Cause mythology to tourists, the Tampa señorita was used by Ybor's Alcalde initiative, the Tampa Chamber of Commerce film The Flower of Tampa, and other promotional materials to depict Tampa as a place of hospitality and sensuality. ${ }^{1}$ Yet unlike the belle, and her accompanying ensemble of plantations, magnolia trees, iced tea, and fictionalized Uncle Remus-like former slaves, Ybor boosters used señoritas to market Tampa as an exotic-but safeborderland between Latin America and the American South. ${ }^{2}$ After describing the creation and utilization of the señorita, this

City': Miami From Frontier to 'Roaring Twenties,' Thesis (Ph.D.) - University of Florida, 2015.

\footnotetext{
2 Karen L. Cox discusses marketing a fictionalized Deep South to tourists from the late 1800 s to the 1950s in, Dreaming of Dixie: How the South Was Created in American Popular Culture, (Chapel Hill: The University of North Carolina, 2011), see especially pgs. 51-57. The belle also furthered "an ideal of femininity that was southern in origin."
} 
article then shifts to examine the tractable ${ }^{3}$ female cigarmaker, another feminine Latin archetype that was used by Tampa cigar industrialists to operate the increasing number of cigar manufacturing machines that were used in factories after the 1920s. Even though the city's cigar workforce was reduced from over 10,000 in 1929 to approximately 6,000 by 1950 , cigarmaking was still an important component of Tampa's economy after World War II, and by 1957 nearly $95 \%$ of Tampa cigars were machine-made by women. Like the señorita, female cigarworkers were used to promote Tampa. Yet unlike the señorita, the public image of these laborers were crafted to highlight Tampa's continuing role as a major American cigar manufacturing capital, one without the labor strife of the past thanks to its now-feminized workforce. $^{4}$

Together, señoritas and tractable cigarworkers came to represent a Tampaspecific form of 'gentrified exoticism,' that

\footnotetext{
${ }^{3}$ An American Tobacco Company executive was one of the first factory administrators to argue that women were not bothered by the monotonous nature of cigar machine operating, like men were, and that women were more "tractable." He made this statement in the 1930s, as more machines were being brought into the factories. This idea was often shared by other factory owners--like Stanford Newman--and the Tampa Cigar Manufacturers' Association. Ingalls, Urban Vigilantes in the New South, 46, 158-159 and Stanford Newman, Cigar Family: A 100 Year Journey in the Cigar Industry, (New York: Forbes Custom, 1999).

${ }^{4}$ Although employment in the industry declined dramatically after $1929,10 \%$ of Tampa's civilian workforce still labored in cigar factories in 1950. See Kerstein, Politics and Growth in Twentieth-Century Tampa, 337 (n. 74). For more on the move toward a female workforce see Ingalls, Urban Vigilantes in the New South, 46, 158-159. Nancy Hewitt, "Women in Ybor City: An Interview With a Women Cigar
}

Ybor's promoters marshaled in an attempt to attract tourists and ensure continuing industrial cigar production. Ultimately, however, the failure to build a space for Ybor señoritaism, Tampa's multi-faceted economy, the Cuban Revolution, and the 1962 Corral-Wodiska cigarworkers strike, stymied boosters attempts to transform Ybor into a major tourist attraction. ${ }^{5}$

\section{Making and Marshaling the Señorita}

Dreams of turning Ybor City into a tourist attraction began in the 1930s, as employment in the cigar industry shrunk from over 10,000 workers to approximately 6,000 , and thousands of tourists trekked to Florida after the U.S. economy slowly rebounded after 1932. But reinventing an industrial town known for labor strife, gambling, and corruption, into a tourist destination in a state known for sandy beaches, sunshine, and roadside attractions was no easy task. ${ }^{6}$ Although Tampa was

Worker." Tampa Bay History, Fall/Winter 1985, 161165; Marilyn L. Figueredo, "Cigar Women," Cigar City Magazine, Vol. 2, Issue 7, Nov/Dec 2006, 46-54. ; "Tampa Cigar Output Jumps Sharply Over Last Year," Tampa Morning Tribune, September 3, 1954; "NLRB Studies Cigar Union Vote Request," Tampa Daily Times, August 22, 1956; George Knight, "How to Add to Old Tampa Cigar Factory," Tampa Sunday Tribune, October 13, 1957; "Cigar Making is Thriving," Tampa Tribune, February 18, 1958; "Steady Gains Recorded in Cigar Output," Tampa Tribune, March 12, 1958; Steve Raymond, "Cigarmakers Here Win \$450,000 in Pay Raises," Tampa Tribune, August 27, 1959

${ }^{5}$ For an overview of the digital materials available for Ybor City and Tampa, see Cameron B. LeBlanc, "Preserving the Memory of Ybor City, Florida," Southern Spaces, December 22, 2009.

\footnotetext{
${ }^{6}$ The vast majority of scholarship on Ybor City and the Tampa cigar industry has emphasized the industry's early years and it's "Golden Age" of
} 
home to Henry Plant's well-known Tampa Bay Hotel, unlike Miami the city never developed a robust tourist economy. In fact, even its cross-Tampa Bay rival St. Petersburg attracted more tourists annually in the early 1900s. In short, as one guidebook author wrote in 1940, "once intended to rival the towns of the East Coast as a tourist resort...[Tampa] developed largely into a commercial and manufacturing city, and as a winter playground is far surpassed by St. Petersburg."

From the 1890s to the 1930s, Tampa was instead a cigar-manufacturing center with a large Cuban, Spanish, and Italian immigrant workforce. Although the Tampa Bay Hotel's minarets dominated the city's skyline, cigars and strikes dictated Tampa's

cigarmaking (late 1880 s to the 1930s). Gary Mormino and George F. Pozzetta, The Immigrant World of Ybor City: Italians and Their Latin Neighbors in Tampa, 1885-1985, (Chicago: University of Illinois Press, 1998). Chapter ten of this work considers post-World War II Ybor City, but the postwar years are not its primary subject and the feminization of the cigar workforce and postwar tourist initiatives are not examined. Gary Mormino and Anthony Pizzo, (Tampa: The Treasure City, (Tulsa: Continental Heritage Press, 1983), chapter 7; Susan Greenbaum, More Than Black: Afro Cubans in Tampa, (Gainesville: University Press of Florida, 2002); Irvin D.S. Winsboro and Alexander Jordan, "Solidarity Means Inclusion: Race, Class, and Ethnicity Within Tampa's Transnational Cigar Workers' Union," Labor History, Volume 55:3 (2014), 271-293; Durward Long, "The Historical Beginnings of Ybor City and Modern Tampa." Florida Historical Quarterly, 45 (July 1966): 31-44; Durward Long, "La Resistencia': Tampa's Immigrant Labor Union." Labor History, 6 (Fall 1965): 193-213; Durward Long, "Making Modern Tampa: A City of the New South, 18851911." Florida Historical Quarterly, 49 (April 1971): 333-345; Durward Long, "The Open-Closed Shop Battle in Tampa's Cigar Industry, 1919-1921," Florida Historical Quarterly, 47 (October 1968):101-121; Robert Ingalls and Louis Pérez, Tampa Cigar economy and society, not vacationers. During its so-called cigarmaking "Golden Age," Tampa had over 100-counting both big and small-factories, which employed $50 \%$ of the city's working population in 1910 and $25 \%$ in 1930. Although these percentages declined in the 1930s and 1940s, the industry still employed several thousand workers after World War II. Yet, like Tampa's hopeful tourism promoters, the guidebook author saw the tourist potential for the industrial city, writing, "to me the most interesting thing in and around Tampa is the section of town known as Ybor City. Here you might imagine yourself abroad." 7

World War II, however, put tourism development plans on hold, as war-related industries shaped the city more than

Workers: A Pictorial History, (Gainesville: University Press of Florida, 2003). Chapter 10 of this pictorial work briefly chronicles the decline of Tampa cigarmaking. For a more general study of Tampa in twentieth century see Robert J. Kerstein, Politics and Growth in Twentieth-Century Tampa, (Gainesville: University Press of Florida, 2001). For an examination of elite-sponsored vigilante activity used to control Tampa cigar workers from the $1880 \mathrm{~s}$ to the 1930 s see Robert P. Ingalls, Urban Vigilantes in the New South: Tampa, 1882-1936, (Gainesville: University Press of Florida, 1993). For a history of 'golden era' cigarmaking making in the United States see Patricia Cooper, Once a Cigar Maker: Men, Women, and Work Culture in American Cigar Factories, 1900-1919, (Urbana: University of Illinois Press, 1987). For a look at pre-Disney Florida attractions see Tracy Revels, Sunshine Paradise: $A$ History of Florida Tourism, (Gainesville: University Press of Florida, 2011).

7 George W. Seaton, Cue's Guide to What to See and Do in Florida, (New York, Prentice-Hall, 1940), 69-72. For statistics on cigar industry employment see Kerstein, Politics and Growth in Twentieth-Century Tampa, 53. 
tourist-centered endeavors. ${ }^{8}$ For example, in 1942 businessman Matthew $\mathrm{H}$. McCloskey built a facility "to construct concrete ships for the war effort," just south of downtown Tampa, and the federal government built MacDill Air Field, which was home to 15,000 military personnel by 1944. ${ }^{9}$ But following the war, as the military's footprint shrunk statewide and tourists flooded Florida in record numbers, the idea of turning Ybor into a tourist attraction was resurrected. In 1949 alone, a reported 4.7 million tourists visited Florida and spent a combined $\$ 825$ million, statistics that renewed interest in remaking Ybor. But how could Tampa's promoters market a city best known for organized crime, Cuban and Italian immigrants, and labor strikes? How could they sell a city that

${ }^{8}$ For how the war influenced greater Tampa see Gary Mormino, Hillsborough County Goes to War: The Home Front, 1940-1950, (Tampa: Tampa Bay History Center, 2001).

${ }^{9}$ Kerstein, Politics and Growth in Twentieth-Century Tampa, 94-95; "Military Bases in Florida 1941," Preliminary Military Bases Study: 1942, Year Books Series, No. 1, Data Complied by the Research Division, Florida State Chamber of Commerce, John F. Germany Vertical Clipping File, Folder: MacDill Airforce Base; Scott, Tampa People with a Purpose, 111-115; "We Get the Big Air Base," Tampa Morning Tribune, July 14, 1939; "Base Planned as Beautiful Military City," Tampa Daily Times, December 28, 1939; "Peterson Base to Eventually Cost $\$ 20,000,000$," Tampa Morning Tribune, July 14, 1939.

${ }^{10}$ Tampa's gambling rackets, gang-related murders, political corruption, and other criminal activities of the 1930s and 1940s contributed to its designation as a hellhole. For a look at the growth and development of postwar Tampa see Gary Mormino, "Tampa: From Hellhole to the Good Life," Richard M. Bernard and Bradley Rice, eds. Sunbelt Cities: Politics and Growth since World War II, (Austin: University Press of Texas, 1983), 138-161. Mormino, Land of Sunshine, State of Dreams, 76-77; Liz Cohen argues in 1950 one magazine author called "the hellhole on the Gulf Coast" to America's postwar tourists (Figure 1 and 2)? ${ }^{10}$

The promotional señorita was one answer to this question, and she was widely adopted in a variety of post-World War II tourist-centered marketing campaigns and initiatives in Tampa. Although before the war señoritas had been occasionally used to publicize Tampa's cigar industry, in particular during the La Verbena del Tobaco festivals of the 1930s (Figures 3 and 4), it was not until after the war that Ybor boosters enlisted señoritaism in earnest to rebrand, advertise, and market the "Latinness" of Ybor City and its cigar industry to American tourists, consumers, and investors. ${ }^{11}$

that the division between citizenship and consumption collapsed after World War II, and that the "purchaser as citizen" meant American consumers' purchases, even in excess, stabilized the postwar economy. Thus, purchasing things, like a Florida vacation, both served the national interest and was patriotic, even more so if you drove to Florida in a new car. Cohen, Consumers' Republic, 69.

11 The 1930s La Verbena cigar events/festivals were promotional tools developed to market Ybor and its cigars. For an overview see Emanuel Leto, "Viva La Verbena: Tampa's Original Cigar Festival," Cigar City Magazine, September/October 2007. For an example of a editorial that attempts to remarket and sell Ybor history see D.B. McKay, "Writer Points to Practical Value of Restoring Ybor Old World Charm," Tampa Tribune, April 22, 1951. In this 'historical' piece, McKay described Tampa's relationship to the late nineteenth-century Cuban Revolution and cigar production. About the cigar industry and cigarmakers he wrote, "The Latins employed in the industry and related enterprises... are as a rule good and loyal citizens, supporting the organized charities generously and giving aid to all worthwhile projects and plans calculated to benefit Tampa. Therefore it is not unreasonable that they ask and anticipate united and active support in furtherance of their 
At the forefront of this initiative was Ybor City's Alcalde program. In the early 1950s, Anthony "Tony" Pizzo and other Ybor businesspersons developed the Alcalde initiative to market and encourage investment in Ybor. The Alcalde promotional program was centered on electing a ceremonial mayor/boss of Ybor, whose job it was to publicize the Latin character of the neighborhood and advocate for public and private capital investments in order to redevelop, reinvent, and sell the barrio to tourists. Making its dramatic public debut at the grand opening of the Tampa International Airport in August 1952, the Alcalde program described Ybor as a place of Latin food, Latin business ties, Latin architecture, and Latin señoritas. ${ }^{12}$ In a letter sent to the editor of Life magazine, Pizzo-the first Ybor Alcalde-wrote that Ybor's attractions included "pretty Spanish girls, a distinctive and interesting architecture of old Ybor City buildings, [and] tempting and attractive Spanish foods." Pizzo went on to write that Ybor "has its serious side, too. Tampa and

ambition to create here a beautiful and novel community typical of the land from which they-or there forebears-came, a lodestone for tourists." This statement highlights how much things in Ybor had changed after the 1920s, as McKay was earlier a stalwart conservative opponent of cigarworker unions and other forms of organized labor. For McKay's earlier views on organized labor and his relationship to vigilante committees see Ingalls, Urban Vigilantes in the New South, 105-106, 203.

12 "Tampa International Airport Terminal Dedication Attracts More Than 10,000 Persons," Tampa Morning Tribune, August 18, 1952; "This Is Ybor City-A State of Mind Without Limits" and Richard F. Warner, "And This is Ybor City's Own Alcalde," Miami Herald, October 12, 1952; Paul Wilder, "Birth of a New Nation-Ybor City," Tampa Sunday Tribune, June 15, 1952.
Ybor City are just now advocating to get more Latin American trade and travel."13

Alcalde promotional materials were printed, business trips to Havana and other Latin American cities were scheduled, and politicians and businesspersons were invited to various banquets and balls. All the while, promotional señoritaism-along with Latin food-were marshaled in support of the Alcalde cause (Figure 5, 6, and 7). ${ }^{14}$ The Alcalde developed a 'navy' to participate in Tampa's annual promotional Gasparilla pirate invasion and street parade. ${ }^{15}$ Yet unlike the other ships, the Alcalde naval vessels used pretty señoritas to distract and repel the Gasparilla invaders. Various other events also utilized the Ybor señorita. In a telling memo outlining one Alcalde promotional event, Pizzo was reminded by a local booster to visit Ybor City cigarmaker's social clubs and arrange to have a picture taken with "a dozen domino players who have typical Latin faces...old timers in beret[s] are most appropriate" and not to forget to be accompanied by "pretty señoritas." In yet another instance,

13 Letter from Tony Pizzo to Coles Phinizy, Life magazine editor, and "Announcing the First Annual International Banquet," undated flyer. Both from Box \#1 Academy-Alcalde (1953) Folder: PizzoAlcalde 1953 (Tony Pizzo) (Pt. 1), Anthony P. "Tony" Pizzo Collection at the University of South Florida Special Collections (hereafter cited as USFSC-Pizzo).

14 "50 Mayors, Latin American Officials Are Invited to First Alcalde Banquet," Tampa Morning Tribune, July 9, 1952.

15 Gasparilla is annual Tampa promotional event that began in 1904. It involves a "pirate invasion" and parade through the city. It is sponsored by Tampa's Ye Mystic Crewe, which is largely composed on influential members of Tampa's business community. 
boosters encouraged Pizzo to be accompanied by women "looking like the pick of the Goldwyn Girls." Along with señoritas, Latin food was also central to the Alcalde cause. Spanish bean soup, an Ybor specialty, was served at festivals, causing long soup lines in Ybor streets, and in the mid-1950s one Alcalde official declared war on any "foe or enemy that dares to intrude on or molest the traditions of our world famous Spanish, Italian and Cuban cuisine." 16

Señoritaism and Latin foods were also deployed to promote Ybor during the 1950s' and 1960s' Cigar Week celebrations. The year 1956 marked the $70^{\text {th }}$ year anniversary of Tampa cigar manufacturing, and Tampa businesses and politicians held a weeklong celebration to honor the industry and attract tourists. Cigar Week events included parades, banquets, balls, and the coronation of a cigar king and queen. "Eight pretty girls," all with Latin names, competed

\footnotetext{
16 Letter From Ye Mystic Crew official J.R. Mickler to Tony Pizzo, January 29, 1953, Box \#1 AcademyAlcalde (1953) Folder: Pizzo-Alcalde 1953 (Tony Pizzo) (Pt. 1), USFSC-Pizzo; "Win a Trip to Cuba Gasparilla Festival," promotional flyer, undated, and Memo to Tony Pizzo, September 15, 1952, Box \#1 Academy-Alcalde (1953) Folder: Pizzo-Alcalde 1953 (Tony Pizzo) (Pt. 1), USFSC-Pizzo; The above cited Pizzo folder also includes the following newspaper clippings "Shrimp Boat Ybor Navy Cheerfully Fails Again," Tampa Tribune, undated. "Tony Pizzo Heads Alcalde Group to 'Resist' Gasparilla Invasion," Tampa Tribune, undated. Also see "Ybor Navy Maps Strategy, Readies Defense," Tampa Times, February 9, 1959.

${ }^{17}$ The entire front page of the November 25, 1956 Tampa Sunday Tribune was designated to promoting and romanticizing the industry. Headlines on the front page included "Tampa Cigar Industry 70 years Old," "Worker is Industry's Backbone," "Hand Made Cigars, Pride of Tampa, Have Made City the Smoke Capital of the World." For other stories describing
}

for the crown of Cigar Queen, and the week's festivities utilized señoritas to promote tourism and the importance of the Tampa-Cuba tobacco connection. In 1960, the ties between Ybor's food and promotional señoritaism was prominently displayed when promotional photographs were taken of the annual Cigar Queen serving food to middle-class diners (Figure 8 and 9). ${ }^{17}$

The extensive use of Cuban bread, Spanish bean soup, and señoritas was central to the Alcalde initiative's attempt to craft an amalgamated (Spanish, Italian, Cuba, and American) marketable "Latin" identity, which is evidenced by the Alcalde's red, white, blue, green, and yellow flag design and pledge (Figure 10). The flag intentionally incorporated the colors of the American, Spanish, Italian, and Cuban flags, and at its center was an Ybor cigar made of Cuban tobacco. ${ }^{18}$ The flag was certainly an appropriate symbol of the Alcalde's attempt

Cigar Week and the industry see D.B. McKay, "They Were Looking For Guavas and Found Cigars," Tampa Sunday Tribune, October 30, 1955, 20-C; Tom O'Connor, "Cigar Festival to Mark $70^{\text {th }}$ Birthday of Industry," Tampa Sunday Tribune, November 11, 1956; "Jaycees Plan Revival Here of Cigar Bowl," Tampa Daily Times, November 26, 1956; "Tampa Cigar Story Starts on the Island of Cuba," Tampa Sunday Tribune, November 25, 1956; Wilton Martin, “Parade, Ball Next Saturday Tops Program," Tampa Daily Times, November 26, 1956; "Eight Pretty Girls Vie Here for Title: 'Tampa Cigar Queen,'” Tampa Daily Times, November 26, 1956; "Tampa Pays Tribute to Cigar Industry," Tampa Daily Times, November 28, 1956; "Cigar Luncheon Set Today," Tampa Morning Tribune, November 27, 1956; "Bean Soup in Congress," Tampa Daily Times, February 12, 1958.

${ }^{18}$ Bill Boyd, "Fun-Loving Ybor Latins, With Their Own Flag, Setting Out to Conquer the World," Tampa Tribune, August 29, 1952. 
to create a gentrified Latin exoticism that could be safely consumed by tourists.

Señoritaism and the Alcalde initiative crescendoed in the late 1950s with the unveiling of the Latin Plaza plan. The plan called for the demolition of a large swath of Ybor and the construction of new tourist-oriented infrastructure. Boosters believed the Latin Plaza would transform industrial Ybor into a suitable space for showcasing señoritaism and Tampa's Latin foods (Figure 11). ${ }^{19}$ The plaza was slated to include coffee shops, outdoor cafes serving Cuban bread and coffee, tropical gardens with plants from South America, and Spanish carriages to transport tourists to various sites that included the location of Tampa's first duel, which was of course fought in 1887 "over a beautiful señorita." Pizzo and others argued that the Latin Plaza was essential if Ybor was to be transformed into a tourist mecca and gateway trade area for all of Latin America (Figure 12). Other boosters argued that the Latin Plaza would be as popular as central Florida's Cypress Gardens. Although a few argued, most notably La Gaceta editor Roland Manteiga, that those concerned for Ybor historic fabric should work to protect its actual industrial history and existing infrastructure-not advocate for its destruction and remakingbusinesses in Ybor largely cheered the plan. The Plaza, they hoped, would do for Tampa what the French Quarter had done for New Orleans, and señoritaism was integral to

\footnotetext{
19 “Latin Quarter Movements Unified," Tampa Tribune, January 30, 1956.

20 "Expert Workers Make World's Finest Cigars In Tampa Factories," Tampa Sunday Tribune, January 1, 1933. Westfall, "Don Vicente Ybor, the Man and His Empire: Development of the Clear Havana Industry in Cuba and
}

their vision. Another integral aspect, however, was the continuing production of cigars in Ybor, which was still essential to the area's economy, and founded on women's labor.

\section{Docile Hands at the Machine}

While the Alcalde program held banquets, elections, and paraded señoritas to rebrand Ybor, thousands of other women labored at Tampa cigar machines. The transition to a predominately female labor force in the city's factories began in the 1920s and 1930s, but women had worked in Tampa's tobacco industry since its inception. Although the craft of hand-rolling cigars had generally been a male occupation during the first decades of cigar production, women regularly worked as tobacco strippers, bunchers, banders, and in other capacities in early production. Even though slumping sales in the early 1930s caused cigar manufactures to increase factory mechanization levels and layoff thousands, Tampa continued to be a center of domestic cigar production, particularly of the "Clear Havana" Cuban tobacco variety, and female cigarworkers were the backbone of Ybor's consolidatedyet continuing-large-scale cigar manufacturing. ${ }^{20}$

Florida in the Nineteenth Century," Thesis (Ph.D.)-University of Florida, 1977, 86, 106. The first mechanized factory in Tampa began production in 1889. It failed, however, and hand-rollers ultimately replaced machines. Thus, unlike cigar factories in other American cigar-producing cities, most large Tampa factories production was centered on handrolled cigars before the 1930s. Hav-A-Tampa had a 
The cigar industry consistently employed between 5,000 and 6,000 workers, and though cigarette consumption continued its meteoric rise after the war and into the early 1970s, American cigar consumption steadily grew; ensuring cigar production was still an important partalthough no longer the centerpiece-of Tampa's economy. In 1951, Tampa Tribune reporter J.A. Murray highlighted this reality when he wrote "Tampa cigar factories are vital to the future of Tampa, as the citrus industry is vital to the future of Central Florida, and tourists to all of the state." By

long history of anti-unionism. Campbell, A. Stuart, The Cigar Industry of Tampa Florida, (Gainesville: University Press of Florida, 1939), 28-30, 35, 37.

${ }^{21}$ Aside from a dip in consumer spending on cigars from 1949 to 1952, spending on cigars increased steadily after World War II, from \$547 million in 1947 to $\$ 701$ million in 1969. "Consumer Expenditures for All Goods and Services and For Tobacco Products," Box 1976 \#4, Folder: W\&M Cigar Industry, Sam Gibbons Papers at the University of South Florida Special Collections (hereafter cited as USFSC-SGP). Cigar marketers, unlike cigarettes advertisers, did not target female consumers, thus the vast majority of cigar smokers continued to be men. Tenant, Richard. The American Cigarette Industry: A Study in Economic Analysis and Public Policy, (Hamden:

Archon Books, 1971); J.A. Murray, "Tampa Needs Vital Cigar Industry," Tampa Morning Tribune, September 24, 1951; "Cigar Unions Say Industry Needs Selling, Not Machines," Tampa Morning Tribune, October 5, 1951; J.A. Murray, "Cigar Factories Lured From Tampa By Cheaper Operation Costs in North," Tampa Morning Tribune, September 26, 1951; Stanford Newman, Cigar Family: A 100 Year Journey in the Cigar Industry, (New York: Forbes Custom, 1999), 93; "Cigar Production Total Increases," Tampa Daily Times, July 2, 1949; "Tampa Cigar Production Greatest in Four Years," Tampa Daily Times, November 2, 1950; "Tampa-Made
1949, Tampa cigar firms produced over $500,000,000$ cigars a year, and industry boosters were optimistic about future profits. In 1951, a Tampa trade group predicted $\$ 50,000,000$ worth of cigars would be produced. ${ }^{21}$ In 1952 the city produced over 592,000 cigars, and though the industry did not create new jobs, workers' wages did not stagnate. Instead, new contracts increased thousands of women workers' wages substantially in 1954 and 1959, and in 1961 the city set a production record when over $750,000,000$ cigars were made. ${ }^{22}$

Smokes Total 552,034,047," Tampa Daily Times, January 2, 1951; William Gober, Jr., "State Cigar Industry Booms; \$50 million 1951 Sale Seen," Tampa Sunday Tribune, April 29, 1951; "113 Factories Devoted to Cigar Making," Tampa Daily Times, December 28, 1939. The year 1929 has often been cited as the high production mark of the Tampa cigar industry, when in fact the city produced more cigars in 1961; Kerstein, Politics and Growth in TwentiethCentury Tampa, 53-54, 94, 113, 122-123, 337 (n. 74).

22 “Tampa Cigar Output Hits 592,573,642," Tampa Tribune, January 3, 1953; "Cigar Output Rises, Mostly in Higher Price Brackets," Tampa Tribune, October 2, 1954; Leland Hawes, "Cigar Factories Here Sign Contract With AFL Unions," Tampa Tribune, July 27, 1954; Vernon Bradford, "4000 Cigar Workers Get Raises," Tampa Tribune, January 27, 1954; "Tampa Cigar Output Jumps Sharply Over Last Year," Tampa Tribune, September 3, 1954; "NLRB Studies Cigar Union Vote Request," Tampa Daily Times, August 22, 1956; George Knight, "How to Add to Old Tampa Cigar Factory," Tampa Tribune, October 13, 1957; "Cigar Making is Thriving," Tampa Tribune, February 18, 1958; "Steady Gains Recorded in Cigar Output," Tampa Tribune, March 12, 1958; Steve Raymond, “Cigarmakers Here Win \$450,000 in Pay Raises," Tampa Tribune, August 27, 1959; "Hoffa May Come Here to Woo Hav-A-Tampa Votes," Tampa Tribune, September 30, 1960; "Cigar Union Applauds Teamsters At Cigar Firm," Tampa Tribune, September 8, 1960. 
By 1957, the same year the Alcalde program was advocating for the Latin Plaza, 95\% of Tampa's cigars were machine-made, and women operated nearly every cigar machine in the city. ${ }^{23}$ This was largely due to management prerogatives, as cigar executives actively recruited women to operate machines, arguing that they were better suited for machine-based cigar manufacturing. Some companies even employed women exclusively. For example, when Standard Cigar Company relocated its operations to Tampa in the 1950s, the company recruited female workers solely, hoping that women laborers would undercut what it saw as unnecessary unionization efforts. The company even publicly pronounced it preferred inexperienced women who lived outside of Tampa proper. ${ }^{24}$ Union shops, however, like Corral-Wodiska, also hired women to operate machines, and thus female employment was not synonymous with anti-unionism. It was instead a widespread industry trend. In short, it was clear by the 1950s that most Tampa cigar factory managers agreed with an American Tobacco Company executive who declared that women were not bothered by the

\footnotetext{
23 "Tampa Cigar Output Hits 592,573,642," Tampa Morning Tribune, January 3, 1953; "Cigar Output Rises, Mostly in Higher Price Brackets," Tampa Morning Tribune, October 2, 1954; Leland Hawes, "Cigar Factories Here Sign Contract With AFL Unions," Tampa Morning Tribune, July 27, 1954; Vernon Bradford, "4000 Cigar Workers Get Raises," Tampa Morning Tribune, January 27, 1954; "Tampa Cigar Output Jumps Sharply Over Last Year," Tampa Morning Tribune, September 3, 1954; "NLRB Studies Cigar Union Vote Request," Tampa Daily Times, August 22, 1956; George Knight, "How to Add to Old Tampa Cigar Factory," Tampa Sunday Tribune, October 13, 1957; "Cigar Making is Thriving," Tampa Tribune, February 18, 1958; "Steady Gains Recorded
}

monotony of operating cigar machines and were more "tractable" than male cigarworkers (Figure 13). ${ }^{25}$

Further highlighting the importance of these women workers, was that fact that the vast majority of cigarmakers - in unionized and non-unionized factorieswere important family wage earners. Cigar machine-based manufacturing may have been tedious and monotonous at times, but high wages motivated many women to continue working even after they established families, and with fewer and fewer young adults launching careers in cigar production, workers tended to hold onto their jobs. A study of the industry uncovered that the majority of industry workers were over forty years of age in 1959. A 1962 report revealed that $50 \%$ of Tampa's women cigarworkers were their respective household's primary source of income, even though the vast majority of these women were married to working husbands. Although employment figures in the cigar industry had been reduced-from $50 \%$ percent of Tampa's working population in 1910 to $10 \%$ in 1950 -that $10 \%$ and the approximately 6,000 workers it represented remained important to the economy. ${ }^{26}$

in Cigar Output," Tampa Tribune, March 12, 1958; Steve Raymond, "Cigarmakers Here Win \$450,000 in Pay Raises," Tampa Tribune, August 27, 1959; "Hoffa May Come Here to Woo Hav-A-Tampa Votes," Tampa Tribune, September 30, 1960; "Cigar Union Applauds Teamsters At Cigar Firm," Tampa Tribune, September 8, 1960.

\footnotetext{
${ }^{24}$ Newman, Cigar Family, 97.

25 Ingalls, Urban Vigilantes in the New South, 46, 158-159

${ }^{26}$ Nancy Hewitt, "Women in Ybor City: An Interview With a Women Cigar Worker." Tampa Bay History,
} 
Though the Golden Age of cigarmaking was over, many women were still profitably employed in the industry, and boosters depicted them as content workers happily operating cigar machines.

The 'pretty señorita' and the 'tractable' female cigar machinist were thus created and juxtaposed to feminize Ybor City in an attempt to mold it into a tourist attraction for America's vacationing postWorld War II middle class and a continuing site of large-scale cigar production. This juxtaposition is displayed most prominently in the 1958 film The Flower of Tampa. ${ }^{27}$ This film summed up the optimism of Tampa boosters, while juxtaposing señoritas with docile cigar workers. Sponsored by the Tampa Chamber of Commerce and the Cigar Manufacturers Association of Tampa, the film takes viewers on a Tampa tour that highlights the cigar industry's operations and Ybor's consumable Latinness. In the film, a young Tampa native named Ricky - who has just returned to the city in search of employment-is given a tour of the town which includes a meal at a Latin restaurant, attending the Gasparilla invasion, observing hand and machine cigar manufacturing processes, the crowning of a Latin fiesta queen, a Latin dance performance, and a flirtation with Maria, a cigar factory manager's daughter. The film brings together everything that Ybor's hybrid proponents promoted: señoritas, tractable cigar workers, Latin amusements, and Cuban tobacco cigars. What it did not depict was Tampa's radical labor history, or the difficult task of marketing an industrial

\footnotetext{
Fall/Winter 1985, 161-165; Marilyn L. Figueredo, "Cigar Women," Cigar City Magazine, Vol. 2, Issue 7, Nov/Dec 2006, 46-54.
}

space to American tourists. Nevertheless, boosters hoped and dreamed that the film represented what Ybor had become. But their dreams of reshaping were stymied by political realities.

See The Flower of Tampa here:

https://www.youtube.com/watch?v=UDuM 8yQVrB0

\section{The Failed Attempt to Make Ybor a Tourist Mecca}

Events of the late 1950s and early 1960s undercut señoritaism, cigar production, and the attempted hybriding of Ybor City. First, the death of the Latin Plaza project dashed - what boosters deemedan essential Ybor tourist initiative. It also revealed the limits of señoritaism and the gentrified exoticism boosters were trying to promote. Tampa's City Council ultimately balked at the cost of the Latin Plaza project and refused to fund it. Because of the city's pluralistic economy, Tampa City Council members had divergent agendas, and proved unwilling to invest such a sizeable amount towards a single tourist initiative. The suburban growth economy, local agribusiness, MacDill Air Force Base, and the phosphate industry, were all generally ambivalent about the Ybor City project, as their profits were derived from non-Ybor related industries. Thus, though Ybor boosters wanted to make the neighborhood less industrial and more tourist-friendlyvia the invention of a more marketable

\footnotetext{
27 The Flower of Tampa, 1958, Tampa Chamber of Commerce Collection, courtesy of the Tampa Historical Society, City of Tampa Archives.
} 
history, the demolishment of large sections of Ybor City, señoritaism, and the building of new Latin-esque infrastructure-Tampa's economic realities erected hurdles that thwarted their plans and redirected the interests of local politicians.

City Council ultimately reallocated the bond money slated for the project in the direction of the non-tourist growth economy. Although 3,000 supporters signed a petition protesting the diversion of funds for other capital projects, which included updating the city's water treatment facilities, the city was unwilling to finance the project, especially after a report claimed it would cost well over its $\$ 1.5$ million estimate. ${ }^{28}$ After the Latin Plaza was killed, new plans were later drawn up, one of which included making Ybor a walled city with bloodless bullfights. Yet grandiose plans for Ybor never materialized, and though señoritaism held on in the form of local flamenco dances and Latin festivals, the failure to secure a constructed place for Ybor's señoritas undermined señoritaism's marketing potential.

The idea of Ybor as a gentrified exotic place with señoritas galore was also

28 "Taxes and the Plaza," Tampa Tribune, October 4, 1958; Leland Hawes, "Ybor Said 'Up in Arms Over Killing of Plaza," Tampa Tribune, date unknown, USFSC-Pizzo; "An Open Letter...To the People of the City of Tampa," Tampa Times, October 18, 1958; "Duncan Says Ybor Leader Has Apologized For Blast At City Board In Plaza Row," Tampa Tribune, October 15, 1958.

${ }^{29}$ On a fund-raising visit to Tampa in the early 1950 s, Castro raised a small amount of money and said that the "the Republic of Cuba is the daughter of the cigarmakers in Tampa." For an examination of the links between the Cuban Revolution and Tampa cigarworkers see Louis A. Pérez, Jr., On Becoming Cuban, (Chapel Hill: University of North Carolina challenged by Cuban Revolutionary politics. In November 1961, a confrontation at Ybor City's José Martí Park revealed how volatile Ybor politics could still be. While giving an anti-Castro speech at Martí Park, Luis Aguero was disrupted by Tampa-area residents Elpido Baso and Richard Ysidron. According to police reports, during Aguero's speech Baso and Ysidron rushed the stage, brandished weapons, ripped the microphone from Aguero's hand, tore down an American and a Cuban flag, and incited a riot. Both were arrested and charged with disturbing the peace and displaying a deadly weapon, and Baso and Ysidron received six-month sentences in the city jail. This incident-the likes of which were unfathomable in Tampa's recently opened Busch Gardens or Orlando's later Walt Disney World, along with the establishment of the pro-revolutionary Tampa Fair Play for Cuba Committee, highlighted Ybor's contested political relationship to Cuban Revolutionary politics and the ways in which this relationship made the barrio a decidedly un-touristy locale of political confrontation. ${ }^{29}$

Furthermore, a cigarworker strike undermined the tractable worker construct

Press, 1999), 46-47 and Lillian Guerra, The Myth of Jose Marti: Conflicting Nationalisms in Early Twentieth-Century Cuba, (Chapel Hill: The University of North Carolina Press, 2005), 30; Frank Steven DeBenedictis, "The Cold War Comes to Ybor City: Tampa Bay's Chapter of the Fair Play for Cuba Committee," Thesis, (M.A.) -Florida Atlantic University, 2002, 51. Neva Murray, "Castro's Success in Cuba Fires Wild Celebration in Tampa Area," The Tobacco Leaf, January 10, 1959; Chuck Schwanitz, "Seven Convicted Here in Near-Riot Over Castro," Tampa Times, November 27, 1961; "Two Arrested in Marti Park Fight Get Six Months," Tampa Times, November 28, 1961. 
Ybor promoters had worked so diligently to create since the end of World War II. In 1961, the Tampa cigar industry's fear of losing access to Cuban tobacco became a reality when President Kennedy signed the Cuban embargo order. Both Tampa cigar executives and workers believed that Cuban tobacco was the indispensable element that Tampa's cigar reputation rested on, and that there was no substitute for high-quality Cuban leaf. Although several Tampa manufacturers acquired as much Cuban leaf as possible as rumors of an embargo circulated, when the embargo order was signed it was clear that Tampa's cigar industry would be altered.

With Cuban tobacco shipments blocked, Tampa cigar companies began to lay off employees, which led to labor unrest on the part of allegedly docile women workers. ${ }^{30}$ Factory owners argued that reduced tobacco supplies, thanks to the embargo, made a workforce reduction necessary, and hundreds of workers were let go in a matter of weeks." 31 The layoffs led to worker protests, and on October 2,

30 Kenneth Love, "Cigar Lay-Offs Starting in Tampa," New York Times, February 8, 1962.

31 "600 Cigar Workers Lose Jobs in Tampa," Tampa Times, February 20, 1962.

32 Tom O'Connor, "Workers at Tampa Cigar Factory Accept New Pact," Tampa Tribune, June 27, 1962; "Not Reluctant to Change, Cigar Union Chief Report," Tampa Tribune, June 15, 1962; "Not Reluctant to Change, Cigar Union Chief Reports," Tampa Tribune, June 15, 1962; Chuck Schwanitz, "Cigar Strike Looms by Mid-September," Tampa Times, August 24, 1962.

\footnotetext{
${ }^{33}$ For a sympathetic take on the strikers and a critical view of police action see "Actos de Violencia Frente a Corral-Wodiska, Varias Huelguistas Recibieron Golpes," La Gaceta, October 12, 1962
}

1962, 500 Corral-Wodiska workers, the vast majority of them women, violently struck in reaction to unemployment and new contracts that emphasized speed over quality, and that they claimed disempowered workers. ${ }^{32}$ On the first day of the strike the Tampa Tribune reported that "Latin tempers flared and rocks flew" at Corral-Wodiska as strikers ringed the entrance of the factory and blocked strikebreakers from entering (Figure 14 and 15). ${ }^{33}$ Ultimately fifteen strikers, the majority of them women, were arrested for various offenses-including throwing bricks, cans, paint infused eggs, concrete, and other items on strikebreakers and their vehicles. One car's window was shattered, and strikers allegedly "rushed toward cars they suspected of carrying strike breakers." ${ }^{34}$ The environment around the factory was so frenzied that when strikebreakers left the plant in the afternoon, police officers planned to use fire hoses to disperse any rioting protestors. $^{35}$

and Ronald Manteiga, "As We Heard It," La Gaceta, October 12 and 19, 1962.

34 Two riots were triggered on the strike's first day. The first erupted when six women entered the factory to work in the morning, and the second when the same women left in the afternoon. Nine women and eight men were arrested. "Tempers Flare at Strike-Bound Corral-Wodiska Cigar Plant," Tampa Times, October 8, 1962.

35 Duane Bradford and Fred Smith, "15 Jailed As Cigar Strikers Riot Here," Tampa Tribune, October 9, 1962; Ronald Sustana, "Cigar Strike Vote Set," Tampa Tribune, September 28, 1962; "Strikers Marking Time," Tampa Tribune, October 3, 1962; "Cigar Union Warns on Strikebreaking," Tampa Times, October 4, 1962; "Cigar Workers Extend Contract With Corral," Tampa Tribune, September 
The strike lasted for several weeks, and strikebreakers reported receiving harassing phone calls, having Molotov cocktails thrown at their residences, andin one instance-having a shotgun fired at a strikebreaker's home. In the end the strike failed, and by the mid-1960s only approximately 3,000 cigarworkers were still regularly employed in the industry. Not surprisingly, the promotional passive Tampa cigarworker soon faded from the public view, while the city's economy moved farther and farther away from cigar production. ${ }^{36}$

\section{Conclusion}

Tampa boosters attempted to reengineer, rebrand, and market Ybor City as a tourist destination and locale of continued industrial cigar production after World War II. To reach this objective, Ybor boosters constructed two Latin feminine archetypes. The first, the señorita, was crafted and deployed to attract tourists to Ybor. The second, the tractable female cigarworker, was created to highlight that Tampa was a deradicalized and stable cigar manufacturing capital. Combined, these feminine types were utilized to market and

16, 1962; Chuck Schwanitz, "5 Work at Cigar Plant," Tampa Times, October 9, 1962. Mary Frederickson has argued that southern women's labor history has focused on two distinct sets of women: older heroines and girl strikers. The first were mother figures dedicated to the cause and the latter feisty and often disorderly girls with "intense desire...to define their lives as workers." Although the media sometimes framed the Tampa cigar strikers as feisty, the women on strike-due their age, their roles as essential household earners, and their Latin identities-do not fit easily into either category. Mary Frederickson, "Heroines and Girl Strikers: Gender Issues and Organized Labor in the Twentieth- brand Ybor City as a gentrified exotic Latin tourist destination.

Although boosters' use of Latin feminine types to advertise products and promote industries was far from unique to postwar Ybor City, the simultaneous use of the señorita and tractable cigar workerone strictly promotional and consumption centered and the other industrial and production centered-reveal the Ybor business community's attempt to frame their barrio as a unique place in the postwar American South. Though some Deep South locales used belles, while others-like Miami-used bathing suit-clad women to allure tourists, these promoters constructed a marketing campaign unreplicated in Florida history, a fact that highlights both Tampa's distinctiveness and the difficultly its boosters faced when attempting to craft a postwar brand based on both tourist consumption and continuing industrial production. Even though the reinvention of Ybor as a dual-purpose neighborhood failed to coalesce, their construction and utilization of the señorita and the tractable cigarmaker underscores another aspect of Tampa's unique history. ${ }^{37}$

Century American South," Robert H. Zieger ed., Organized Labor in the Twentieth-Century South, (Knoxville: The University of Tennessee Press, 1991), 85-112.

\footnotetext{
${ }^{36}$ Ronald Sustana, "Cigar Strike Ends; Union Renews Pact," Tampa Tribune, November 17, 1962.

37 Emanuel Leto, "Ybor City Before and After Urban Renewal," Cigar City Magazine, May/June 2008.
} 
Brad Massey is professor of history at Polk State College.
I.j. russum is professor of humanities at Polk State College.

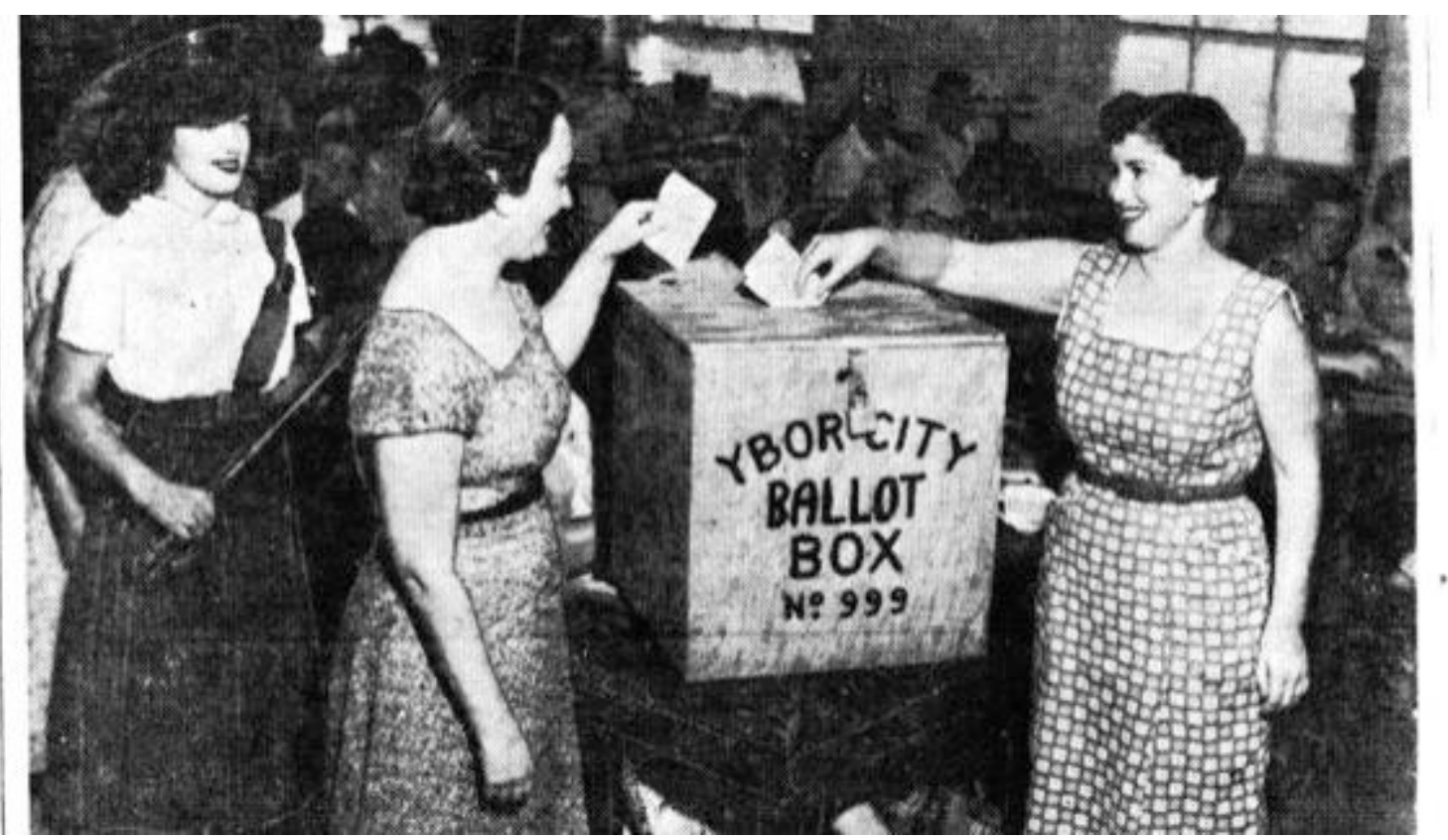

A picture of a 1950s Alcalde election. Note the señorita policing the ballot box while women cigar workers cast their ballots for the ceremonial mayor of Ybor City. The señorita and the female cigarworker were the central symbolic components of the attempt to reinvent Ybor City after World War II. Tampa Daily Times photo, undated newspaper clipping but late 1950s, University of South Florida Special Collection, Anthony “Tony” Pizzo Papers, Box \#1, Folder: Alcalde. 


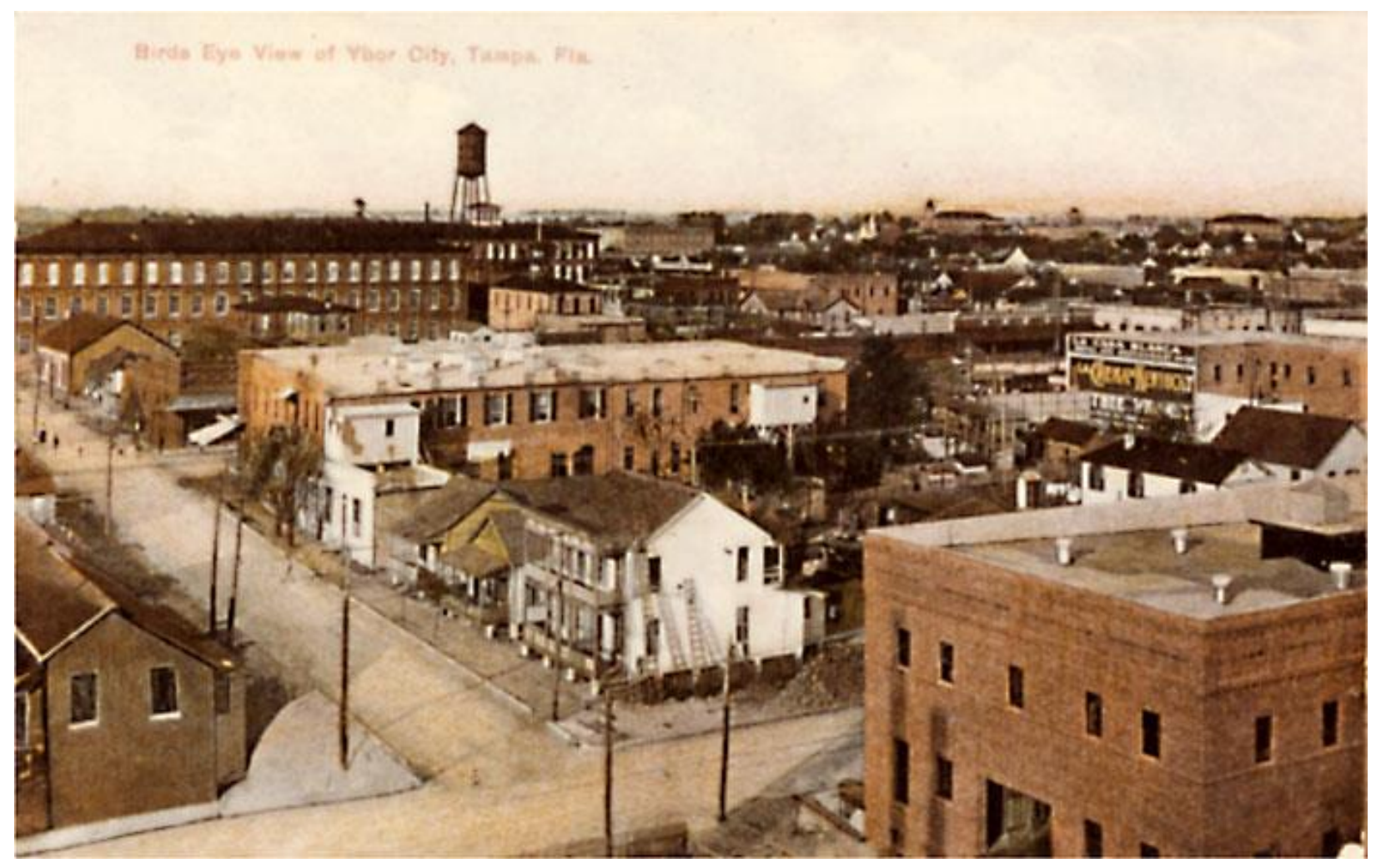

Figure 1: This postcard captures a section of Ybor City during its industrial period. Note how the cigar factories are interspersed amongst residential homes. During the Great Depression, Tampa's cigar industry contracted and many factories closed, causing Ybor boosters to attempt to reinvent this industrial neighborhood, best known for its large immigrant population, labor radicalism, elitesponsored vigilante committees, and political corruption. Courtesy of the Special Collections Department, University of South Florida. 


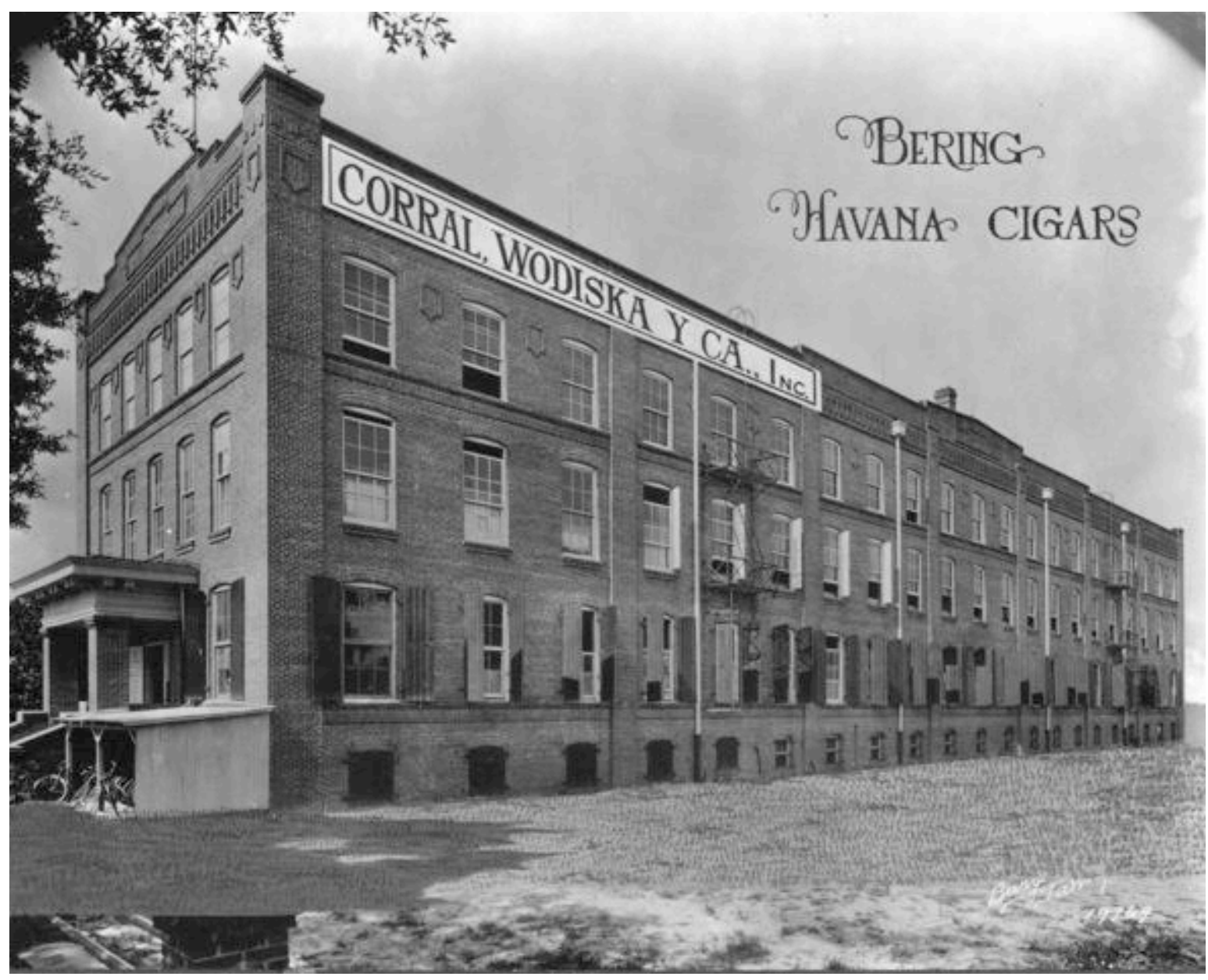

Figure 2: The Corral-Wodiska factory was one of the most important postwar factories, and was the location of a 1962 strike. Hundreds of factory photographs, like this one, were taken of Ybor's cigar production centers during its pre-Great Depression industrial heyday. Note the caption "Bering Havana Cigars." Up until the Cuban Embargo, which drastically altered the industry, Corral-Wodiska and other Tampa factories' reputations and branding efforts were based on Cuban tobacco. University of South Florida Special Collections, Florida Studies Center Gallery, Burgert Brothers Collection of Tampa Photographs, Photo Taken in 1926. 


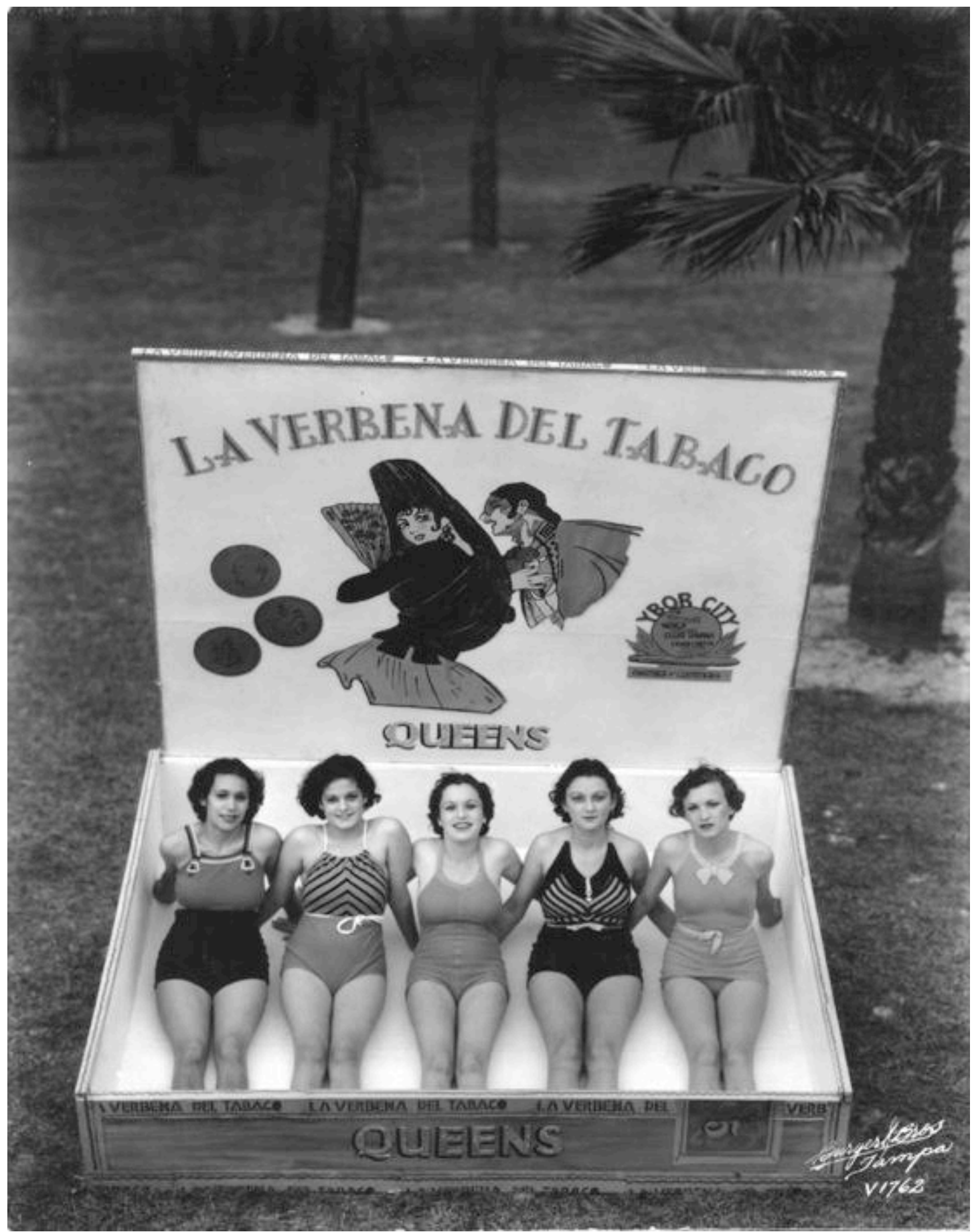




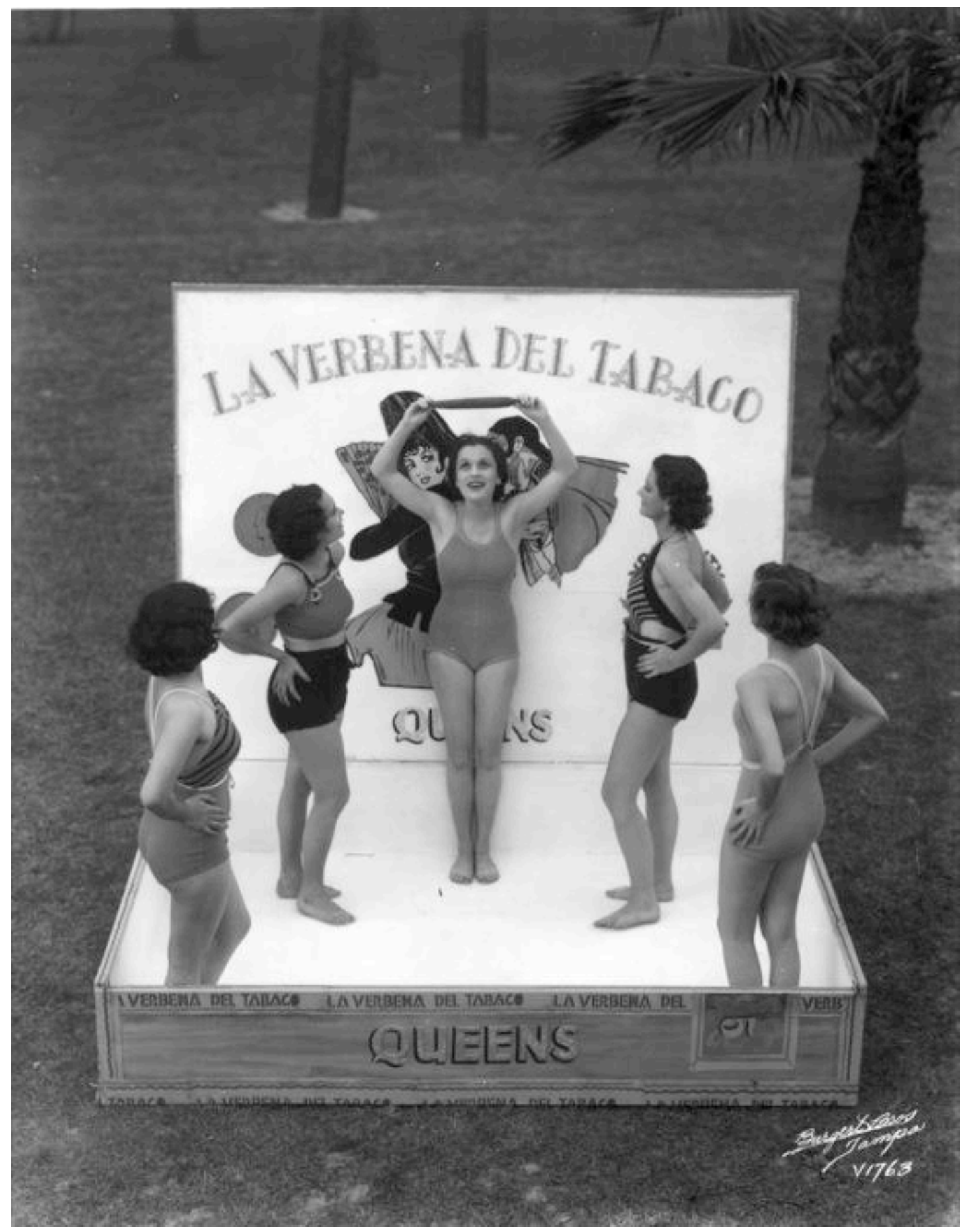

Figures 3 and 4: The above two photographs are from the 1937 La Verbena cigar festival and marketing campaign. Both highlight the early prewar attempts to use señoritaism to sell cigars and Ybor City. Note that the women are packaged and ready to be sold to consumers. Also note the Ybor City emblem on top right-hand section of the open cigar box lid in figure 4 . The campaign was a precursor to the full-scale attempt to use señoritaism to market Ybor City to tourists after World War II. University of South Florida Libraries Digital Collection, Burgert Brothers Photography Collection, "La Verbena del Tabaco Festival Queens," 1937. 


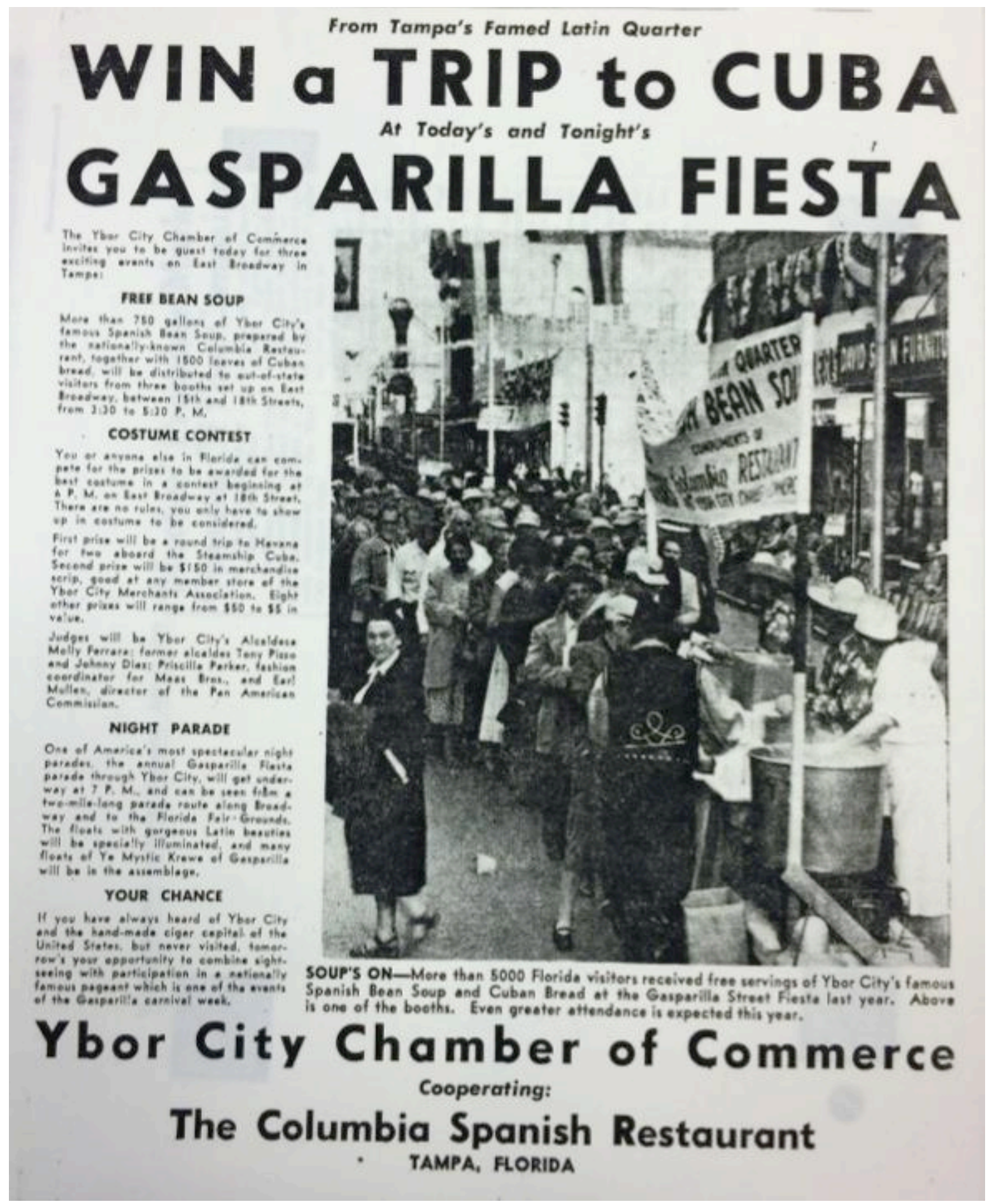

Figure 5: Along with señoritaism, food and ties to Cuba were central components of the Alcalde initiative. Note the long soup line and the trip to Cuba trip giveaway. USFSC-APP, Box \#1, Folder: Alcalde, flyer undated, but likely mid-1950s. 


\section{Ole! Dancers for Alcalde Ball}

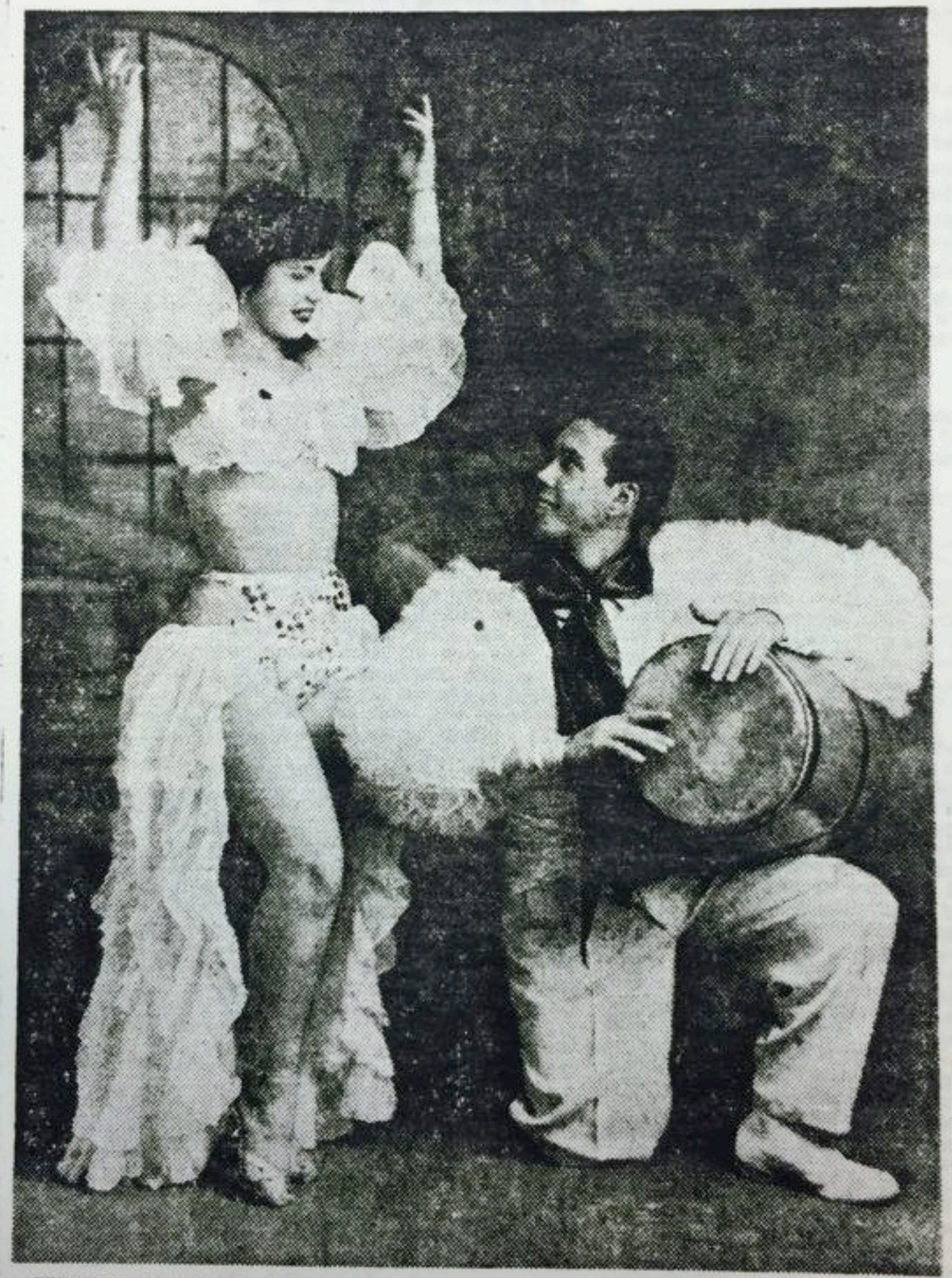

WILL TAKE SPOTLIGHT-Marta Munoz and Jorge Rodriguez will execute two colorful dance numbers during the floor show at the Alcalde Inaugural Ball tomorrow night at the Cuban Club patio. 10-29-54 


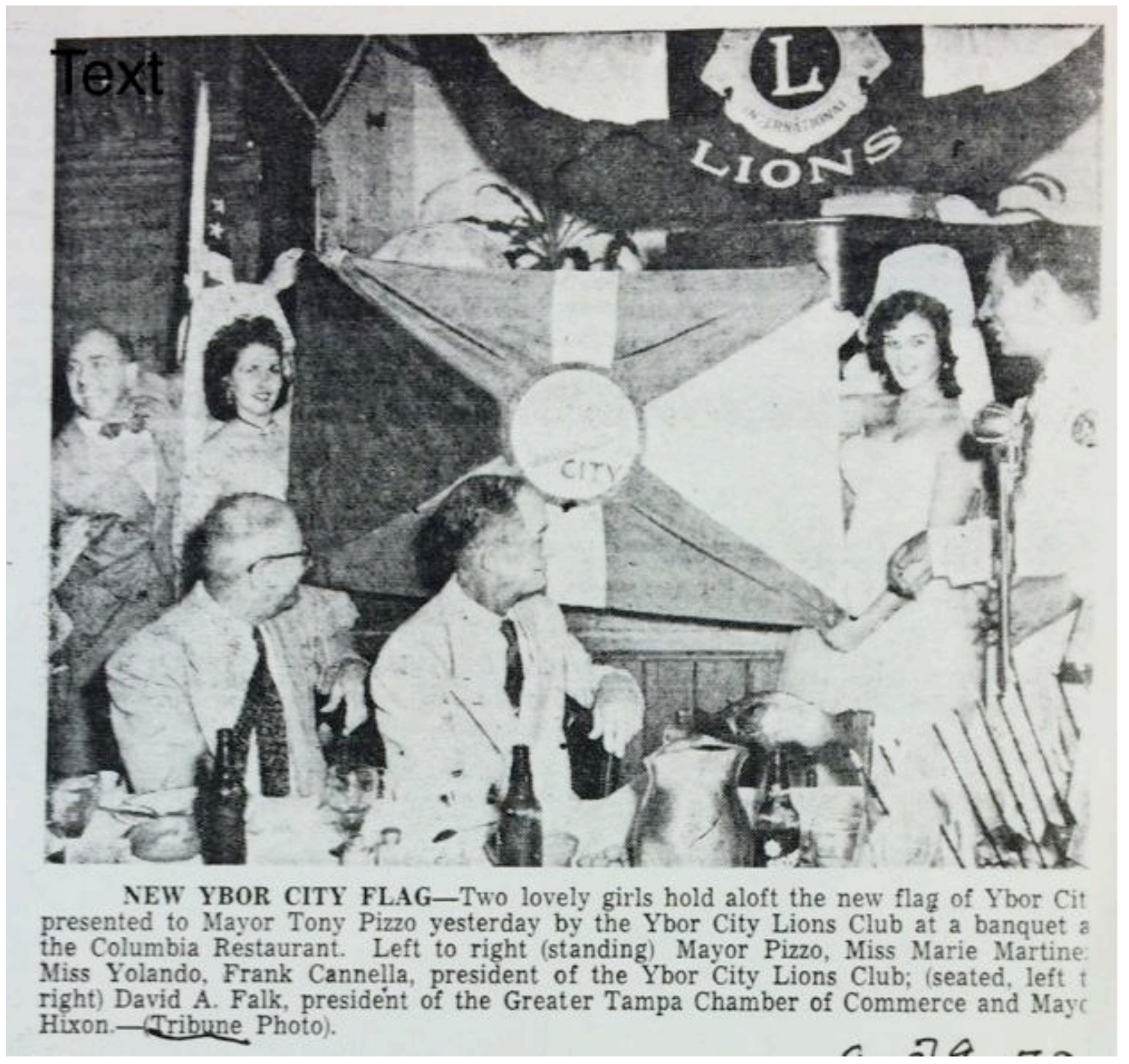

Figures 6 and 7: The above Tampa Tribune photographs highlight the use of the "pretty señoritas" at promotional events. Figure 5 was taken at an Alcalde ball and Figure 6 at a banquet attended by Tampa Mayor Curtis Hixon and other local power brokers. Note that the señoritas are holding an Alcalde flag in the bottom photo. The man standing on the far right-hand side of the photo is Tony Pizzo, the first Alcalde of Ybor. Figure 5 TampaTribune, October 29, 1954 and Figure 6 Tampa Tribune, August 29, 1952. 


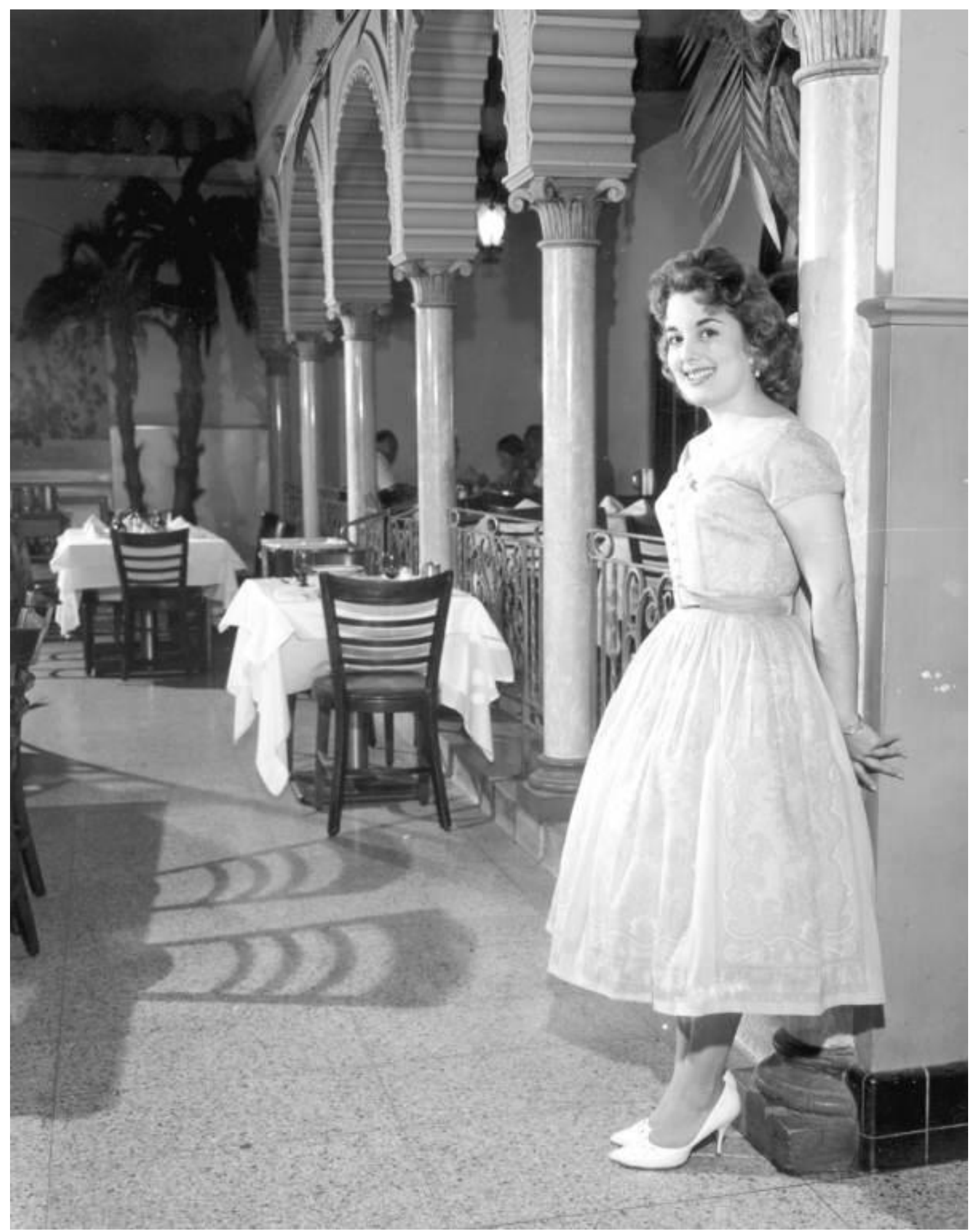




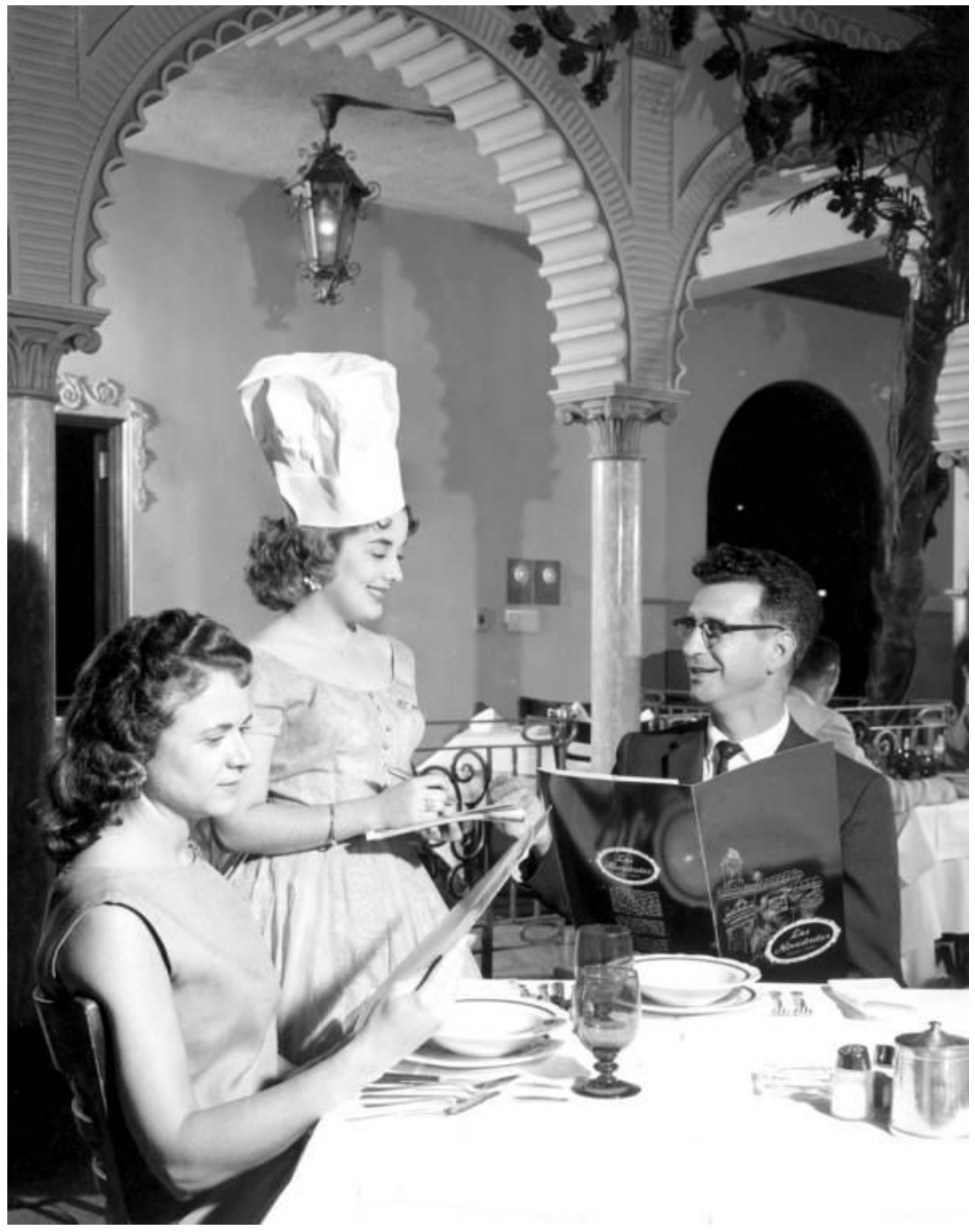

Figures 8 and 9: Photos of the 1960 Cigar Queen posing and serving food to middle-class patrons in an Ybor City restaurant. Tampa's Cigar Queen was invented to publicize Tampa as both a tourist destination and a locale of continuing cigar production. The photos highlight the connection between promotional señoritaism and food. Both photos Courtesy of State Archives of Florida, Florida 
Memory Photographic Collection, Photos Taken by Charles Barron, Image Numbers C032995 and C032990, 1960.

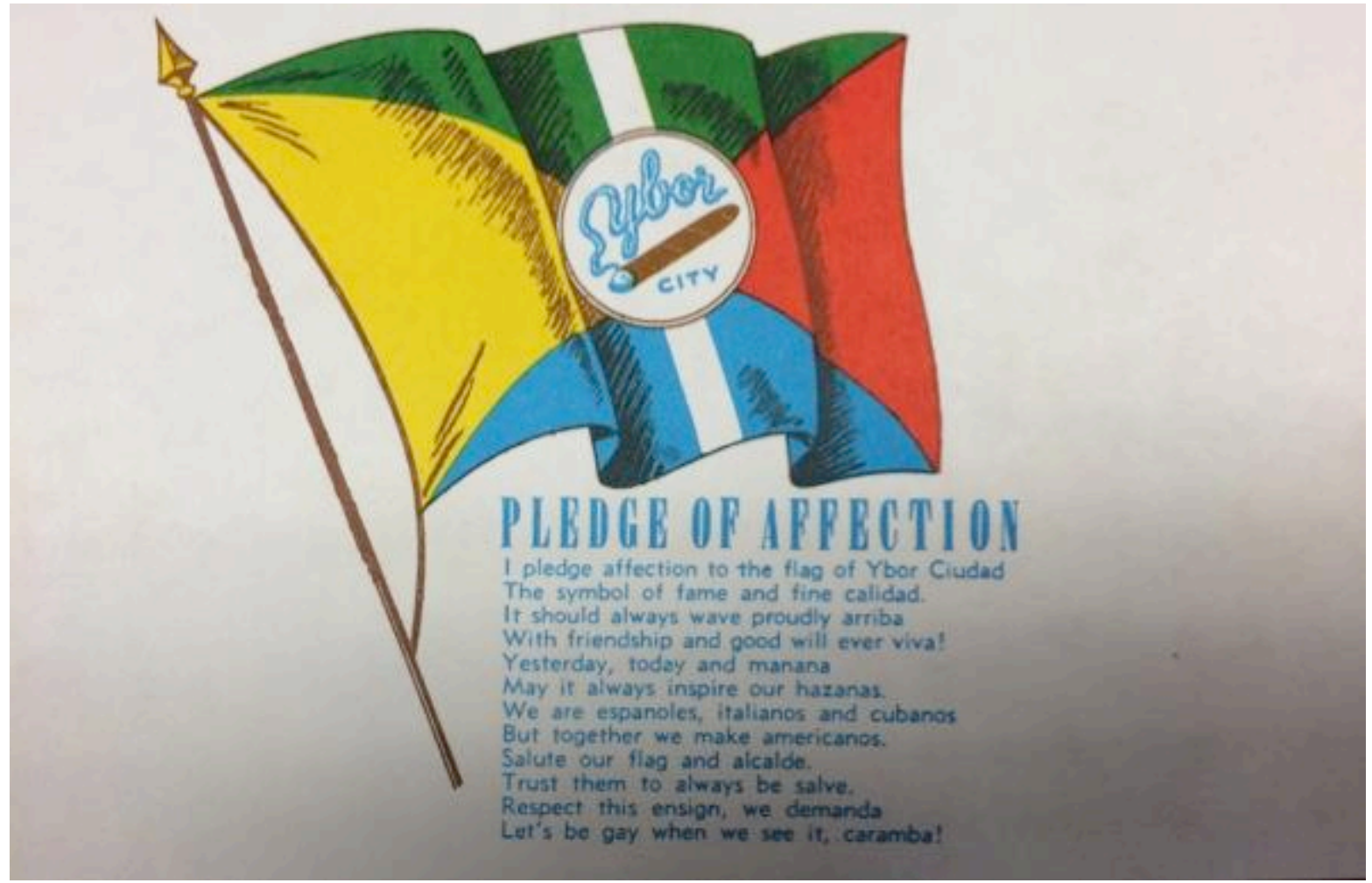

Figure 10: A promotional card with the Alcalde flag and pledge. Note the colors and cigar in the center. Also, note how the text merges "espanoles, italianos, and cubanos" into one distinct Latin group of "Americanos" for marketing purposes. The flag is a symbol of the Alcalde's attempt to create consumable gentrified exoticism. USFSC-Pizzo, Box \#1, Folder: Alcalde. 


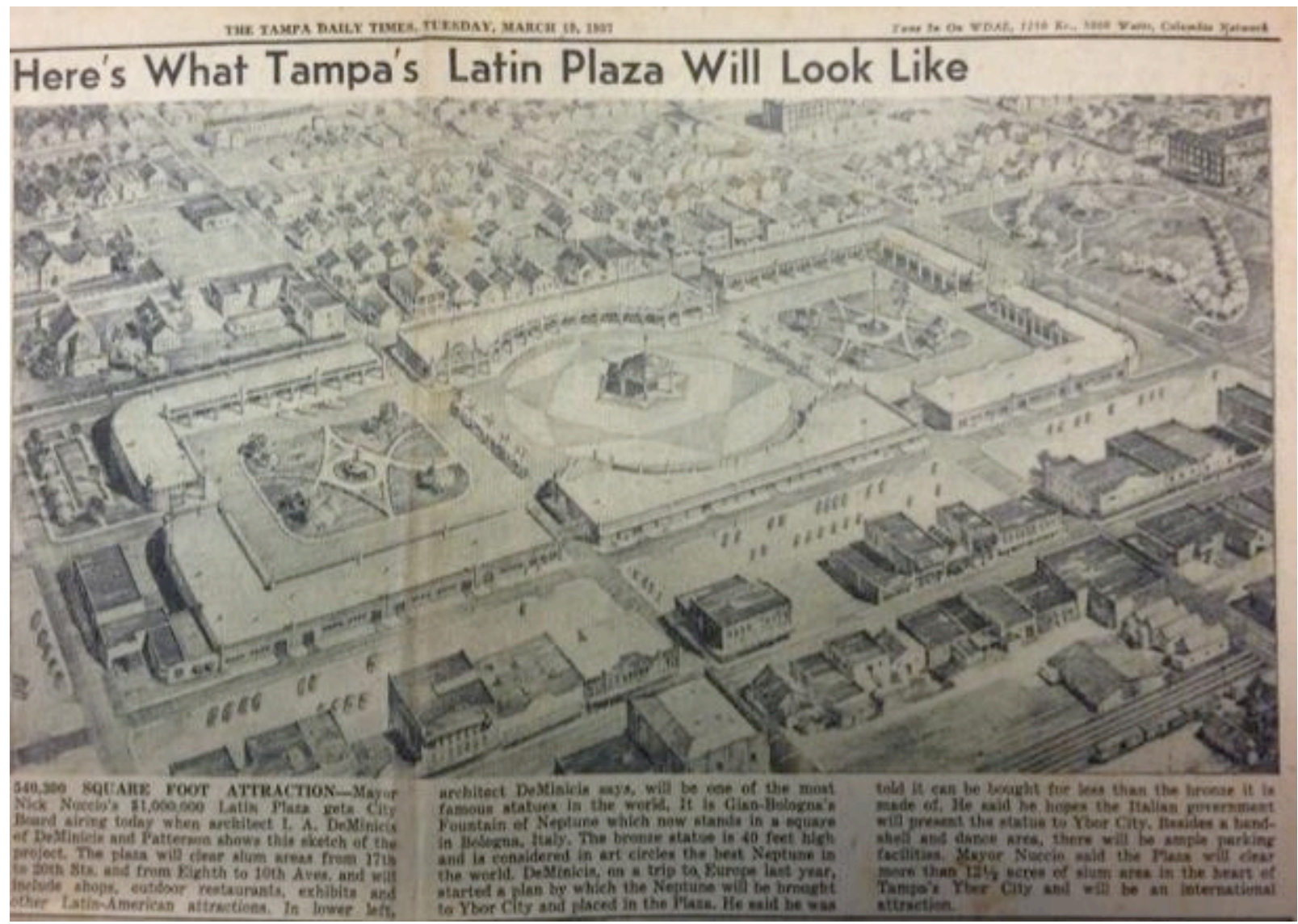

Figure 11: Artistic rendering of the Latin Plaza. The plaza was to be the centerpiece of a reinvented Ybor, and home to several 'Latin' food and entertainment vendors, as well as a constructed space for consumable señoritaism. Tampa Daily Times, March 19, 1957. 


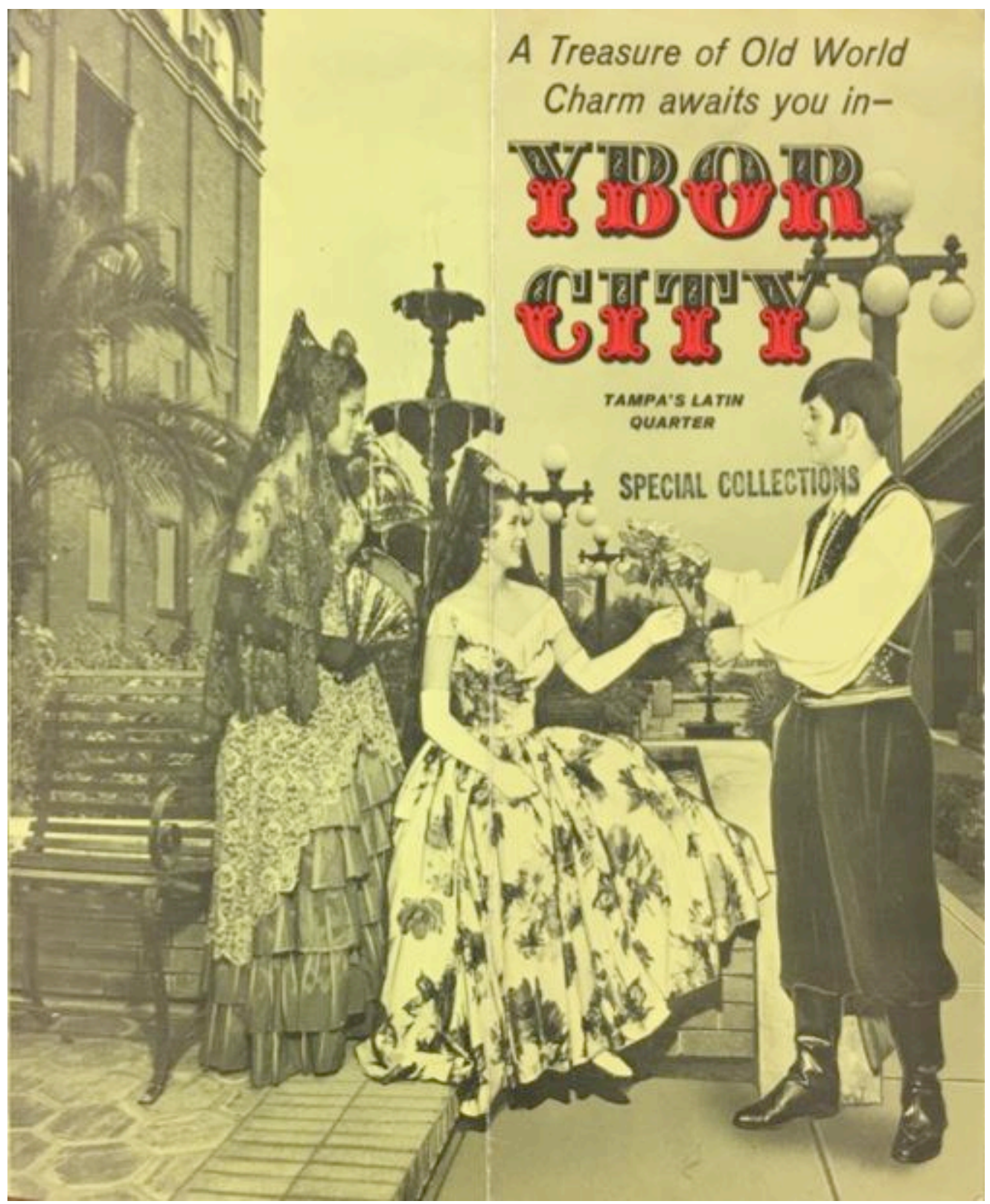

Figure 12: In this Ybor City promotional pamphlet, we see two 'Old World' versions of the señorita. The 'Old World' señorita was used to connect Ybor to traditional Spanish customs, which were far removed for Ybor City's actual industrial history and reality, but were central to the Latin Plaza project. John F. Germany Public Library, Vertical File Collection, Folder: Ybor City. 


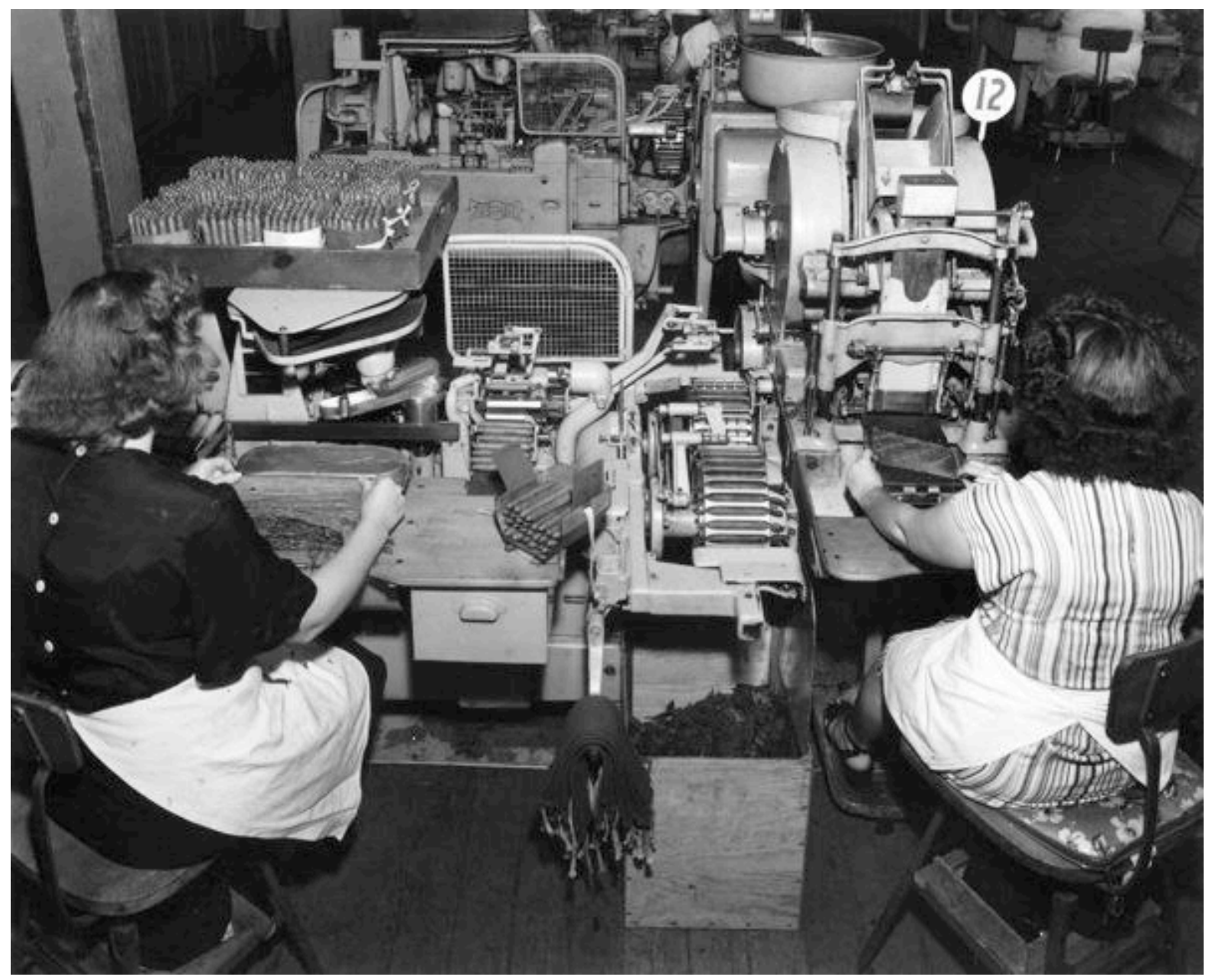

Figure 13. This 1949 picture captures the labor of two of the thousands of women that operated cigar machines in Tampa after the war. Nearly every postwar cigar industry photograph that chronicled women's labor, mimicked the framing style shown above, in that they pictured faceless woman, engaged in labor, not looking at the camera. University of South Florida Libraries Digital Collection, Burgert Brothers Photography Collection, "Women Making Cigars at Machines at Swann Products, Incorporated," Image \# B29-00065252 


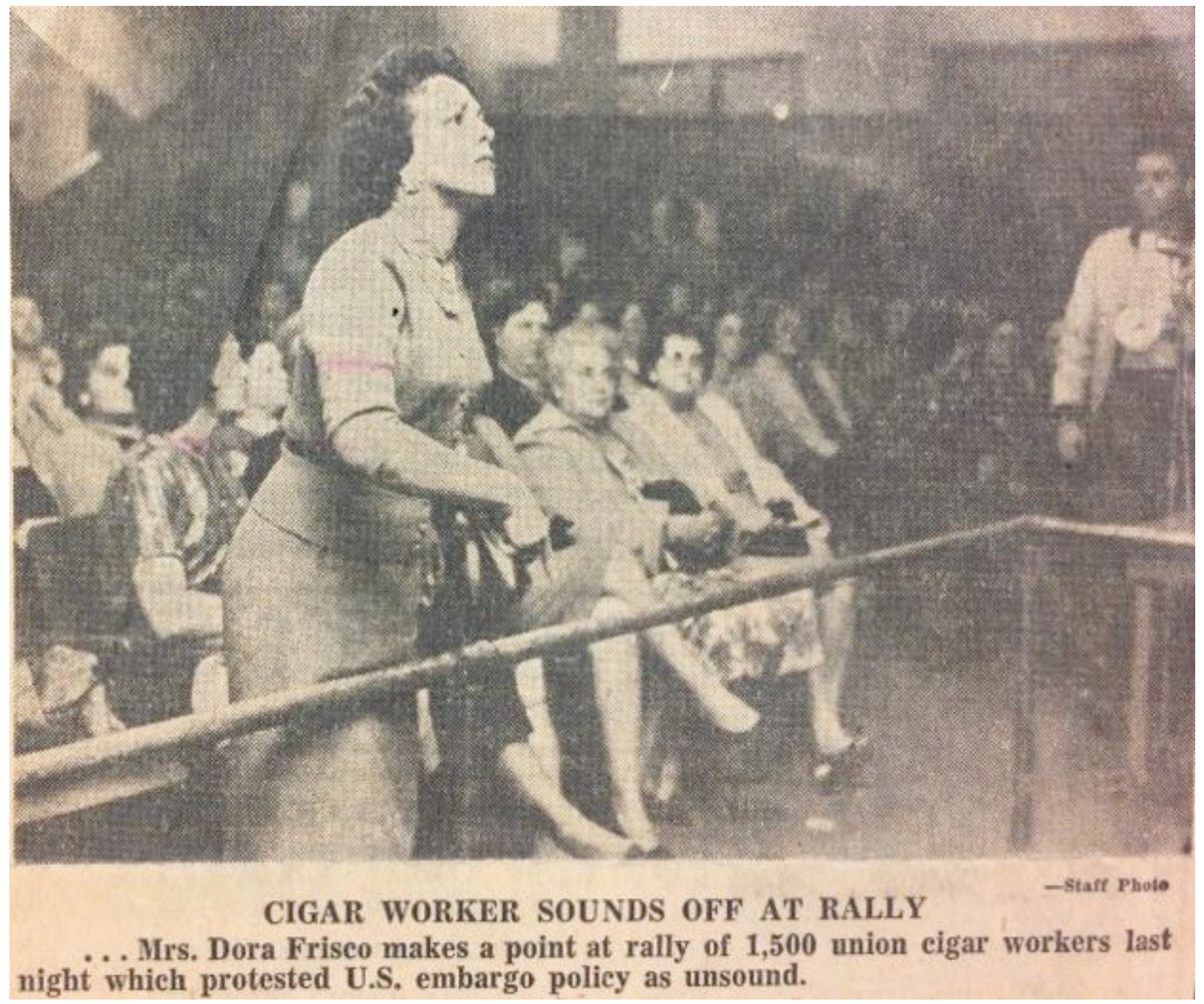

Figure 14: The above Tampa Times photo is of a disgruntled cigar worker angered over the Cuban Embargo. Scenes like these and the Corral-Wodiska strike challenged the 'tractable' cigar worker archetype boosters' crafted in the 1950s. Tampa Times, March 8, 1962. 


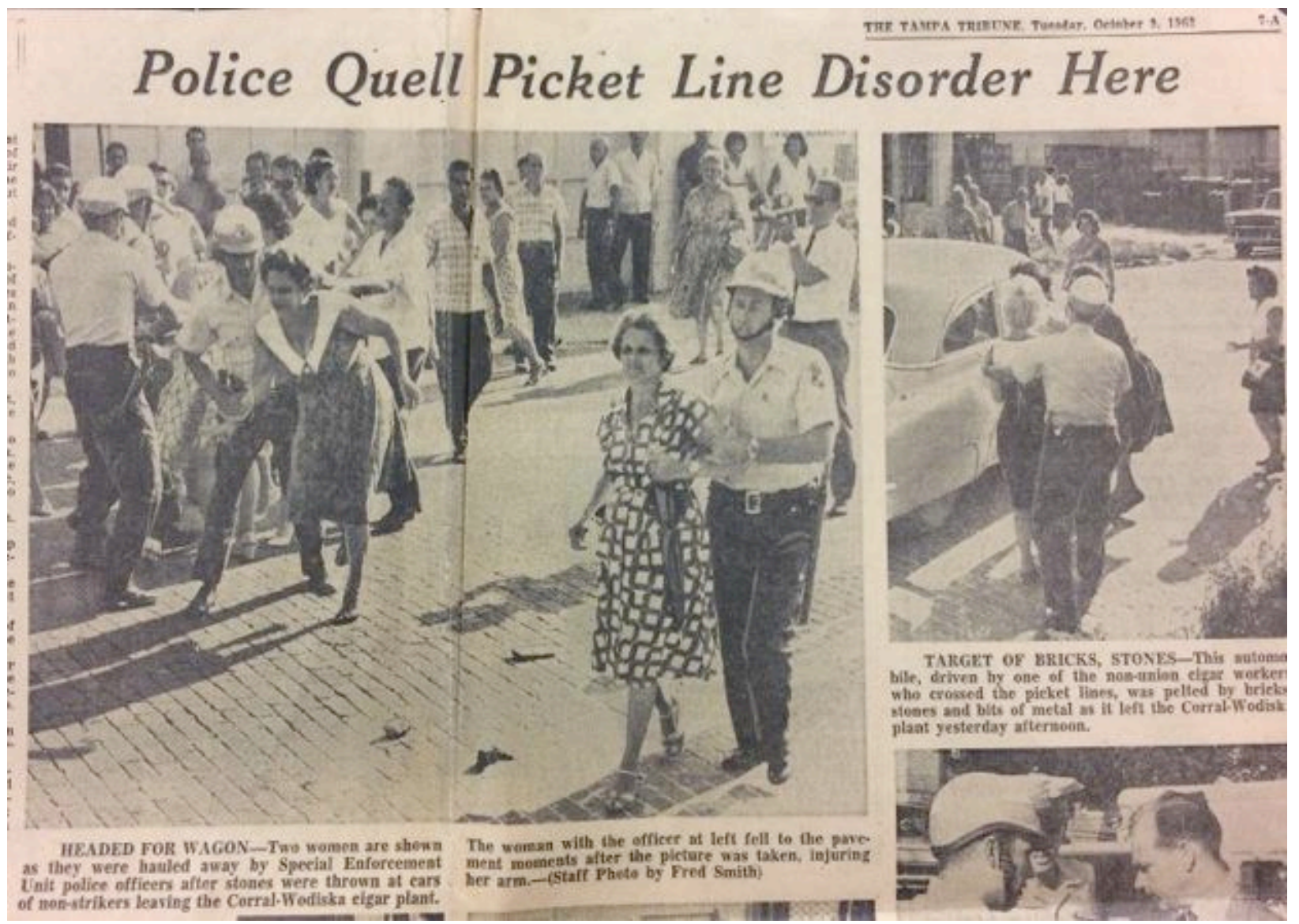

Figure 15: Fifteen women were arrested in front of the Corral-Wodiska factory on the 1962 strike's first day. The women that struck at the Corral-Wodiska factory challenged the postwar construct of the docile female cigar worker, which boosters' marshaled in an attempt to make Ybor a place of tourism and stable industrial production divorced from Tampa's radical labor past. Tampa Tribune, October 9, 1962. 